IZA DP No. 8628

Country of Origin and Immigrant Earnings, 1960-2000: A Human Capital Investment Perspective

Harriet Orcutt Duleep

Xingfei Liu

Mark Regets

November 2014 


\title{
Country of Origin and Immigrant Earnings, 1960-2000: A Human Capital Investment Perspective
}

\author{
Harriet Orcutt Duleep \\ College of William and Mary and IZA \\ Xingfei Liu \\ IZA and Renmin University of China \\ Mark Regets \\ National Science Foundation and IZA
}

Discussion Paper No. 8628

November 2014

\author{
IZA \\ P.O. Box 7240 \\ 53072 Bonn \\ Germany \\ Phone: +49-228-3894-0 \\ Fax: +49-228-3894-180 \\ E-mail: iza@iza.org
}

\begin{abstract}
Any opinions expressed here are those of the author(s) and not those of IZA. Research published in this series may include views on policy, but the institute itself takes no institutional policy positions. The IZA research network is committed to the IZA Guiding Principles of Research Integrity.

The Institute for the Study of Labor (IZA) in Bonn is a local and virtual international research center and a place of communication between science, politics and business. IZA is an independent nonprofit organization supported by Deutsche Post Foundation. The center is associated with the University of Bonn and offers a stimulating research environment through its international network, workshops and conferences, data service, project support, research visits and doctoral program. IZA engages in (i) original and internationally competitive research in all fields of labor economics, (ii) development of policy concepts, and (iii) dissemination of research results and concepts to the interested public.
\end{abstract}

IZA Discussion Papers often represent preliminary work and are circulated to encourage discussion. Citation of such a paper should account for its provisional character. A revised version may be available directly from the author. 


\section{ABSTRACT \\ Country of Origin and Immigrant Earnings, 1960-2000: A Human Capital Investment Perspective*}

Using microdata from the 1960-2000 decennial censuses, this paper explores how large initial differences in immigrant earnings by country of origin change with duration in the United States. One analysis reveals that country of origin adds less to the explanation of earnings, among working-age adult male immigrants, the longer they reside in the United States. Another discovers that the earnings dispersion of demographically comparable immigrants across countries of origin diminishes with time in the United States. Both indicate convergence in immigrant earnings by country of origin. To probe the sensitivity of these results to immigrant emigration, we pursue a theoretical analysis, which gauges how hypothetical patterns of selective emigration affect the convergence results, and an empirical analysis, which could be more broadly applied as a test for emigration bias. Both suggest that immigrant earnings convergence by country of origin is not an artifact of emigration. The convergence has methodological ramifications for the measurement of immigrant economic assimilation - in studies that follow cohorts and in studies that follow individuals with longitudinal data - and more generally for the study of any process in which unmeasured variables jointly affect initial conditions and subsequent growth.

JEL Classification: J1, J2, J3

Keywords: immigrant economic assimilation, human capital investment, country of origin, immigrant earnings convergence

Corresponding author:

Xingfei Liu

IZA

Schaumburg-Lippe-Strasse 5-9

53113 Bonn

Germany

E-mail: liu@iza.org

\footnotetext{
* We are grateful to Bob Topel and Yoram Weiss for their comments on earlier versions of this paper. We are also grateful for comments and suggestions on this paper from Massimiliano Tani, Matloob Piracha, Amelie Constant and other seminar participants at the 9th IZAWorld Bank Conference on Employment and Development (Lima, Peru, 2014 June) and to Yu Li and other seminar participants at China Center for Human Capital and Labor Market Research Central, University of Finance and Economics (Beijing, China, 2014 June). Past discussions with Michael Leonesio and David Weaver informed and illuminated the theoretical model that forms the foundation for this research.
} 
Country of Origin and Immigrant Earnings, 1960-2000:

A Human Capital Investment Perspective

\begin{abstract}
Studies that have described immigrant cohorts, assessed the progress of immigrants in the United States, and examined the role of ethnicity in labor market behavior have assigned to country of origin a prominent part. Jasso and Rosenzweig (1986, p. 75)
\end{abstract}

\title{
I. INTRODUCTION
}

As the first economist to theoretically model how country of origin might affect immigrant economic assimilation, Chiswick (1978a, 1979) proposed several hypotheses relating country-specific factors (such as English speaking) to the degree to which source-country skills transfer to the host-country labor market. Jasso and Rosenzweig (1986, 1990a) identified source-country attractiveness, economic conditions, and costs of migration as key factors in country-of-origin's effect on immigrant earnings. The focus of this paper is how country-of-origin earnings' effects change as immigrant men live in the United States. ${ }^{1}$

Twentieth-century America experienced a sea change in the country-of-origin composition of its immigrants. The demise of a U.S. immigration quota system based on national origin and its replacement in 1965 with an admission policy emphasizing family reunification opened the gates to a large and increasing flow of immigrants differing in national-origin composition from prior immigrant flows. Once primarily European, U.S. immigration became predominantly Asian and Hispanic.

Accompanying the source-country transformation was a precipitous decline in the entry earnings of working-age immigrant men relative to U.S. natives - a decline that is most apparent since the 1960's when U.S. immigration policy changed from a national-origins system favoring Western European immigration to a family-based policy. ${ }^{2}$ In 1960, working-age immigrant men who entered the United States in 1955-1959 earned on a par with U.S. natives. After 1965, the median initial earnings of immigrant men ages 25-54 as a percent of U.S.-natives' median earnings plummeted: in 1970, those entering the United States in 1965-69 earned 65\% of natives' earnings; in 1980, the 1975-79 entrants earned 50\% of natives' earnings; and, in 1990, the 1985-89 entrants earned $41 \%$ of natives' earnings. These differences remain largely intact when immigrants and natives are categorized by age and years of schooling. Current Population Survey data matched to Social Security longitudinal earnings records tell a similar story. The median earnings of working-age men (ages 25-60) who entered the U.S. in 1960-64 were 100\% of native-men's earnings in 1965, 71\% in 1970 (for the 1965-69 immigrant cohort), 61\% in 1980 (for the 1975-79

\footnotetext{
${ }^{1}$ The role of country/region of origin has been explored in numerous contexts, including its effect on English proficiency (Chiswick and Miller, 1992; Kossoudji, 1988; Rivera-Batiz, 1992), educational attainment (Chiswick and DebBurman, 2004), location choice and admission category (Jaeger, 2007), the labor market effects of immigration (Bohn and Sanders, 2007; Angrist and Kugler, 2003; Pischke and Velling, 1997; Rivera-Batiz and Sechzer, 1991 ; Gang and Rivera-Batiz, 1994a), women's labor force behavior (Reimers, 1985), immigrant unemployment and union membership (DeFreitas, 1991, 1993), immigrant concentrations and businesses (Andersson et al., 2010), attitudes towards immigrants (Gang and Rivera-Batiz, 1994b), immigrant selectivity (Jasso and Rosenzweig, 1990b; Bauer et al., 2002), immigrant enclaves (Bauer, Epstein and Gang, 2005), employer training of immigrants (Barrett et al., 2013), immigrant welfare use (Hansen and Lofstrom, 2009), and many other contexts.

${ }^{2}$ The dramatic decline in the initial earnings of U.S. immigrants can be measured with decennial census data. We used the 1980 5\% "A" PUMS, the 1970 1\% State PUMS based on the 5\% questionnaire, and the $19601 \%$ PUMS (Bureau of the Census, 1983, 1977, and 1975). Although the 1960 census did not collect year-of-immigration information, place of residence in 1955 let us identify immigrants who entered the U.S. between 1955 and 1960.
} 
cohort), and 54\% in 1984 (for the 1982-83 cohort), a decline that persists weighting the foreign born and native born to the same age and years-of-schooling distribution (Duleep and Dowhan, 2002).

The coincidence in timing between the change in immigrants' source-country composition and the decline in immigrants' initial earnings suggests that the former caused the latter. Weighting the 1980 initial earnings of immigrants who entered the U.S. in 1975-1979 by the pre-1965 country-of-origin immigrant mix almost eliminates the large foreign/native differential; rather than earning half of U.S. natives' earnings, recently arrived immigrants in 1980 would have earned on a par with their U.S.-born contemporaries had the pre-1965 source-country mix continued. Yet, the importance of large initial earnings differences associated with country of origin depends on what those differences represent and whether they persist, increase, or diminish. Low initial earnings associated with high human capital investment creates a profoundly different social and economic scenario than low initial earnings associated with low labor market ability.

Part II presents the case that the post-1965 decline in immigrants' education- and age-adjusted entry earnings was caused by decreases in the proportion of U.S. immigrants with skills that immediately transfer to the U.S. labor market. Building on Chiswick's Immigrant Assimilation Model, ${ }^{3}$ Part III articulates a human capital investment perspective that predicts that county-of-origin earnings' effects caused by variations in skill transferability diminish as immigrants live and work in the United States. Such a human capital investment perspective, in addition to predicting immigrant earnings convergence, suggests specific guidelines for measuring immigrant economic assimilation. The failure to use these guidelines - regardless of whether analysts follow individuals or synthetic cohorts - misrepresents immigrant economic assimilation (Part IV). Guided by the methodological lessons of a human-capital-investment perspective, two complementary cohort analyses follow. Using 1960 through 1980 decennial census data, Part V measures the importance of country of origin with immigrant time in the United States during the period when changes in U.S. immigrant source-country composition and the accompanying decline in immigrant entry earnings were most intense. Part VI probes the sensitivity of these results to emigration. The paper's penultimate section examines whether the convergence results hold for other, more recent, immigrant cohorts.

\section{BEHIND THE GREAT IMMIGRANT ENTRY EARNINGS’ DECLINE}

A plausible explanation for the post-1965 drop in U.S. immigrants' education- and age-adjusted entry earnings is a post-1965 decline in the proportion of immigrants with skills that immediately transfer to the U.S. labor market: the less country-of-origin skills transfer to the U.S. labor market, the lower the initial earnings of immigrants (Chiswick, 1978a, 1979). Two developments associated with the 1965 change in immigration law likely spurred a decline in immigrant skill transferability.

\section{Immigration from Less-Economically-Developed Countries Increased}

One development was a change in the source-country mix of U.S. immigration from economically developed to less economically developed countries. The national-origin quota system (in place from the 1920's to 1965) favored immigration from the economically developed countries of Western Europe and excluded or severely restricted immigration from other, less economically developed, countries. With the demise of the national-origin quota system, immigration from less economically developed countries rose (D. Reimers, 1996).

Two theories link immigrants' skill transferability to the economic development level of the

\footnotetext{
${ }^{3}$ See Chiswick (1978a, 1979).
} 
countries they come from. Holding constant the level of human capital (years of schooling and work experience), Chiswick (1978a, 1979) speculates that immigrants hailing from economically developed countries have skills that transfer easily to the U.S. because these countries share similar educational systems, industrial structures, and labor-market reward structures with the U.S.; the skills of immigrants from less economically developed countries transfer less readily to the U.S. labor market (initially resulting in lower U.S. earnings) because the formal education and work experience in these countries are less applicable to the U.S. labor market.

Duleep and Regets $(1997 \mathrm{~b}, \mathrm{c})$ suggest another theory that links immigrants' skill transferability to the economic development level of the countries they come from. Rather than reflecting variations in the skills learned by growing up and working in different source countries, U.S. immigrants from less-developed countries have lower skill transferability because the limited opportunities in less-developed countries make it worthwhile for individuals to migrate, even when immigration entails substantial post-migration investments in new skills and credentials such as learning English, undertaking additional training, or starting a business; their statistical twins in economically developed countries would only migrate if there were positions for them in the U.S. that immediately valued their source-country skills, and they did not have to invest in new human capital.

Regardless of the underlying etiology, the initial earnings of U.S. immigrants do, on average, increase with the economic development level of immigrants' source countries. Immigrants from regions of the world with levels of economic development similar to the U.S., such as Western Europe, have initial earnings approaching or exceeding those of comparably educated and experienced U.S. natives; those hailing from the economically developing countries of Asia and Central America have low initial earnings relative to their U.S.-born counterparts (Table 1). When we regressed the median 1989 entry earnings of immigrant men in the 1985-1990 cohort on source-country per capita gross domestic product we found that the initial earnings of immigrant men increase 2,280 dollars for each 10-percentage-point increase in per capita GDP ${ }^{4}$. Given this relationship, it isn't surprising that as immigration from less-economically-developed countries increased, the initial earnings of U.S. immigrants decreased.

\section{A Decrease in Initial Earnings for the Same Countries}

In addition to the change in the source-country composition of U.S. immigration, the pre-1965 national-origins admission program affected how prospective migrants responded to the post-1965 admission program, with predictable effects on the skill-transferability (hence initial-earnings) of immigrants from the same source countries.

The Immigration and Nationality Act of 1965 eliminated country-specific quotas that discriminated against particular groups and introduced a system of restricted and non-restricted admission categories greatly favoring immigrants with family members in the United States. It also made some room for employment-based immigration: under this law, in effect until 1990, 20

\footnotetext{
${ }^{4}$ The $\mathrm{R}^{2}$ for this regression is .48. The 1987 per capita GDP of each source country is per adult GDP as a percent of the U.S. per adult GDP. The observations on U.S. median earnings for immigrant men and per capita GDP are for the following countries: Argentina, Australia, Bangladesh, Bolivia, Brazil, Canada, Chile, China, Colombia, Costa Rica, Czechoslovakia, Dominican Republic, Ecuador, Egypt, El Salvador, Fiji, France, West Germany, Greece, Guatemala, Guyana, Haiti, Honduras, Hong Kong, Hungary, India, Indonesia, Iran, Ireland, Israel, Italy, Jamaica, Japan, Jordan, The Republic of Korea, Laos, Malaysia, Mexico, Morocco, Myanmar, Netherlands, New Zealand, Nicaragua, Nigeria, Pakistan, Panama, Peru, Philippines, Poland, Portugal, Romania, South Africa, Spain, Sri Lanka, Sweden, Switzerland, Syria, Taiwan, Thailand, Trinidad and Tobago, Turkey, U.S.S.R., United Kingdom, Venezuela, and Yugoslavia. All countries for which we had information on the GDP per adult were included. Median earnings for immigrant men in the 1985-90 cohort from the aforementioned 65 countries were estimated using a 6 percent microdata sample created by combining and reweighting the 1990 Census of Population 5\% and 1\% Public Use samples. The statistics on GDP per adult as a percent of U.S. GDP per adult are from Heston and Summers (1991).
} 
percent of the numerically restricted visas were allocated to applicants on the basis of their occupational skills. ${ }^{5}$ The very nature of the employment-based admission process (entailing employers hiring immigrants with specific occupational skills for specific jobs) insures that employment-based immigrants will have higher initial U.S. earnings, than family-based immigrants - a prediction confirmed by several analyses. ${ }^{6}$

When the immigration policy changed in 1965, the national origins legislation had been in place for some 40 years. Potential migrants from countries that had previously faced severe U.S. immigration restrictions lacked U.S. family members. Unable to secure a U.S. footing via the family admission programs, qualified prospective migrants immigrated via the employment-based admission categories. As these employment-based immigrants established a U.S. base, their relatives - with less transferable skills - followed, using the family-based admission categories to become U.S. immigrants. In this way, the proportion of U.S. immigrants, from the same source country, lacking skills that immediately transfer to the U.S. labor market, grew in the years following 1965. This scenario explains why the entry earnings of immigrants from several Asian countries declined in the post-1965 era. For instance, the 1970 earnings of working-age Korean men who entered the U.S. in 1965-1970 were $75 \%$ of the earnings of working-age U.S.-born men; the 1990 earnings of the 1985-90 Korean immigrant cohort were $44 \%$ of the corresponding U.S.-born benchmark.

In summary, a transformation in the source-country composition of U.S. immigration, from economically developed to less economically developed likely contributed to a post-1965 decline in U.S. immigrant skill transferability of U.S. immigrants. In addition, prior immigration restrictions in conjunction with the post-1965 employment- and family-based admission categories contributed to a post-1965 decline in immigrant skill transferability, hence initial earnings, for immigrants from specific countries.

\section{WHY WE WOULD THEORETICALLY EXPECT COUNTRY-OF-ORIGIN EFFECTS TO DIMINISH WITH TIME}

Chiswick (1978a, 1979) theorized that when immigrants enter the U.S., or other host country, they lack (in varying degrees) the skills specific to that country that would enable their human capital to be fully valued in the labor market of their new home. To increase the labor market value of their source-country human capital, immigrants engage in various forms of human-capital investment such as learning English, pursuing informal and formal schooling and training, and becoming knowledgeable about the destination country's institutions, production methods, and technical terms. As English and other host-country-specific skills or credentials are gained, the labor market value of the immigrant's source-country human capital is restored.

Building on Chiswick's Immigrant Assimilation Model, Duleep and Regets (1999, 2002) articulated an Immigrant Human Capital Investment (IHCI) model that formalizes Chiswick's concept of skill transferability to the host-country's labor market while highlighting the human-capital-investment implications of two other aspects of skill transferability. One, immigrants whose source-country skills do not fully transfer to the destination country's labor market will, by virtue of their lower wages, have a lower opportunity cost of human-capital

\footnotetext{
${ }^{5}$ The occupational skills (or employment-based) classification embraced two components: workers, skilled and unskilled, in occupations for which labor is deemed scarce, and professionals, scientists, and artists of exceptional ability.

${ }^{6}$ Jasso and Rosenzweig (1995), Duleep and Regets (1996a, b) and DeSilva (1996) all find that employment-based immigrants start their host-country lives with higher earnings than their family-based statistical twins. However, family-based immigrants have higher earnings growth and, with time, the earnings of family and employment-based immigrants converge.
} 
investment than natives or immigrants with high-skill transferability. ${ }^{7}$ Two, source-country human capital that is not valued in the destination country's labor market is useful for learning new skills. Persons who have learned one set of skills have advantages in learning new skills; they have learned how to learn. Moreover, common elements between old and new skills aid learning. ${ }^{8}$ Combining the lower opportunity cost of human capital investment with the usefulness of the undervalued human capital for learning implies that low-skill transferability immigrants will be more likely than natives or high-skill transferability immigrants to invest in human capital in general, as opposed to or in addition to human capital that "only" restores the labor-market value of their original source-country human capital. ${ }^{9}$

Thus three principal considerations link low skill transferability to high investment in human capital, hence high rates of earnings growth, and suggest that the initial divergence in immigrant earnings by country of origin will diminish with duration in the United States. Higher rates of immigrant human capital investment will occur for immigrants with low skill transferability because: (1) host-country skills make source-country skills more usable in the host-country labor market; (2) the opportunity cost of learning new skills is lower when initial U.S. earnings opportunities are low; and (3) skills not immediately valued in the host-country labor market are useful for learning new skills. Because low-skill-transferability immigrants will invest more than high-skill-transferability immigrants (holding initial human capital levels constant), there will be an inverse relationship between entry earnings and earnings growth. Across groups, the lower the entry earnings, the higher the earnings growth and over time, as entry earnings fall (rise), earnings growth rises (falls). ${ }^{10}$

In summary, a human capital investment perspective predicts that source-country earnings' effects will diminish with time in the United States to the extent that these effects reflect variation in immigrants' initial U.S. skill transferability. This will be true regardless of whether skill-transferability differences stem from variations in the skills learned growing up and working in different source countries (as suggested by Chiswick), or from an opportunity-driven selection mechanism (as suggested by Duleep and Regets), or both.

\section{METHODOLOGICAL IMPLICATIONS OF A HUMAN CAPITAL INVESTMENT PERSPECTIVE}

Beyond predicting country-of-origin convergence in immigrant earnings, a human capital investment perspective prescribes a strategy for measuring immigrant economic assimilation that diverges from the path generally taken.

Whether using pooled cross-sections (where analysts exploit cross-sections from multiple years to follow year-of-entry immigrant cohorts over time) or longitudinal data on individuals, analysts typically pool immigrants who have entered their destination country at different points in time and estimate a variant of the following model: $\log y_{i}=X^{\prime} \beta+\gamma^{\prime} C_{j}+\alpha^{\prime} Y S M+\varepsilon_{i}$ where $y_{i}$

\footnotetext{
${ }^{7}$ The time they spend learning new skills, instead of applying their current skills to earning, is less costly than it is for natives or for high-skill transferability immigrants, who earn more with the same level of schooling and experience.

${ }^{8}$ For more discussion on this point, refer to Duleep and Regets (1999, 2002).

${ }^{9}$ This may explain why Green (1999) finds a greater propensity of immigrants to change occupations than natives beyond what can be explained by an assimilation effect; the timing of the changes across year-of-entry cohorts suggests that they are in response to an evolving demand for different types of labor-market skills. A topic for further research, along the lines pursued by Green, is what are the effects on a nation's economic productivity of the skill acquisition of immigrants that accompanies their high earnings growth? In addition to the ideas in the Chiswick and Duleep/Regets models, an alternative or contributing factor in the propensity to invest in human capital is an individual's propensity to undertake risk. Direct evidence on risk attitudes and migration is explored in Jaeger et al. (2010).

${ }^{10}$ The inverse relationship is predicted by Chiswick's Immigrant Assimilation model and gains further support via Duleep and Regets' IHCI model.
} 
denotes the earnings of immigrant $\mathrm{i}$; $\mathrm{X}$ is a vector of variables measuring education and experience, and $B$ the corresponding coefficients; YSM measures years since migration; and $C_{j}$ is a set of dummy variables representing each year-of-immigration category, $\mathrm{j}$.

The original impetus for this model was to control for unobserved variables that affect immigrant earnings and vary with year-of-entry cohort. Analysts believed that including a categorical (aka dummy) 0-1 variable for each year-of-entry immigrant cohort controls for cohort differences (not captured by observed variables) in immigrant earnings trajectories. An important assumption underlying this methodology is that (once observable variables are controlled for) changes in the entry earnings of immigrant cohorts are not accompanied by changes in earnings growth. In stark contrast, a human capital perspective predicts that (controlling for initial levels of human capital) decreases in entry earnings are systematically accompanied by increases in earnings growth, and vice versa.

With a systematic inverse relationship between entry earnings and earnings growth, the dummy-variable cohort methodology produces misleading results in all situations where entry earnings (adjusted for observable variables) change. Specifically, in analyses that pool year-of-entry cohorts and include a dummy variable for each year-of-entry cohort, the earnings growth estimate (the estimated coefficient on years since migration) is an average of the earnings growth rates of all of the year-of-entry cohorts. With an inverse relationship between entry earnings and earnings growth, the actual earnings growth of a recent cohort with lower initial earnings than earlier cohorts (controlling for age and education) will be higher than the preceding cohorts' earnings growth; an estimate based on the average of the earnings' growth rates of all the year-of-entry cohorts underestimates its earnings growth. The actual earnings growth of a recent cohort with higher initial earnings than earlier cohorts will be lower than the preceding cohorts' earnings growth; an estimate based on the average of the earnings' growth rates of all the year-of-entry cohorts overestimates its earnings growth. ${ }^{11}$

This qualification holds whether the analyst's focus is the study of all immigrants - where changes in initial earnings may arise from changes in the source-country composition of U.S. immigration - or the study of U.S. immigrants from a single country—where inter-cohort changes in immigrant entry earnings may reflect changes in that source-country's level of economic development or the admission programs its emigrants use to become U.S. immigrants. More generally, by not allowing earnings growth to change as entry earnings change, the dummy-variable cohort approach obfuscates important inter-cohort transformations in immigrant earnings paths while failing to control for unobserved variables that affect immigrant earnings and vary with year-of-entry cohort. Since cohorts that vary in their entry-level earnings systematically vary in their earnings growth, each year-of-entry cohort should, ideally, be separately examined, thereby freeing its earnings-trajectory estimation from the paths of other cohorts.

Analysts also typically incorporate all possible year-of-entry cohorts in their analysis, including those for which the available earnings information only begins years after the immigrants' initial year of entry. Yet, to avoid implicit assumptions about the relationship between entry earnings and earnings growth, the analyst should include only year-of-entry cohorts that can be followed from the immigrants' initial years in the host country. This approach, though reducing the information that is used, insures that conclusions are not the result of an assumed relationship between immigrants' entry earnings and earnings growth. ${ }^{12}$

A human capital perspective further suggests that returns to schooling and experience will differ markedly between high- and low-skill transferability immigrants. Since low-skill transferability immigrants will be more engaged in human capital investment than

\footnotetext{
${ }^{11}$ See also Green and Worswick (2012) on this and related points.

${ }^{12}$ Note that this approach avoids confounding effects of age and assimilation and the choice of an appropriate reference group (see, for instance Kossoudji, 1989 and Lalonde and Topel, 1991).
} 
high-skill-transferability immigrants, the estimated returns to cumulative levels of schooling and experience, in an earnings regression for a given year, will (at least in the initial years of immigration) be much lower for low-skill-transferability immigrants than for immigrants with highly transferable skills. This argues, once again, for examining each year-of-entry cohort separately since cohorts that vary in their entry-level earnings will systematically vary in their human-capital investment patterns.

In fact, the very practice of controlling for years of schooling in immigrant earnings estimations likely depresses the measured earnings growth of immigrants with low initial earnings relative to immigrants of similar age and education level with high initial earnings. According to a human-capital investment perspective, the former will invest in more schooling in the host country than the latter. By controlling for education levels, the resulting higher earnings growth is missed and convergence between the two groups, underestimated.

Finally, a human capital investment perspective cautions against the common practice of excluding from the sample individuals with zero earnings and the self-employed. ${ }^{13}$ In studies that follow immigrant cohorts across two or more cross-sections, such as censuses, these sample selection rules make the two census samples unrepresentative of each other and unrepresentative of the same cohort at two points in time: Individuals excluded from the initial census sample because they are unemployed or out of the labor force, perhaps because of job search or time spent in school, may be fully employed, hence included, in the second census sample; immigrants may also move from wage and salary jobs (thereby included in the first census sample) to self-employment (thereby excluded). These issues apply to any cohort followed between censuses (or other data sources), but are particularly important for the study of immigrant economic assimilation since immigrants have high occupational mobility, high in-school rates, and a high propensity to become self-employed. ${ }^{14,15}$

Sample comparability is not an issue when analysts follow the same individuals with longitudinal data. Nevertheless, excluding zero earners omits immigrants who are pursuing job search and learning, instead of earning. Excluding such individuals likely understates immigrant earnings growth in general and in particular for groups with low initial skill transferability, while having less effect on earnings growth estimates for immigrant groups characterized by high initial skill transferability. Excluding the self-employed may also understate immigrant earnings growth, particularly for groups with low initial skill transferability. Gallo and Bailey (1996), Bailey (1987), Portes and Bach (1985), and Waldinger (1989) document an immigrant sector in various industries characterized by mutually beneficial arrangements in which recent immigrants working as unskilled laborers at low wages (or even no wages) in immigrant-run businesses receive training and other forms of support that eventually lead to more skilled positions or self-employment. ${ }^{16}$

The importance of these methodological considerations, and in particular the importance of allowing earnings growth to vary in tandem with entry earnings, can be illustrated by examining how immigrant earnings growth changed during the great immigrant entry earnings' decline. Keeping in mind the methodological guidelines inspired by a human-capital investment perspective - allowing earnings growth to vary with initial earnings, separately examining each

\footnotetext{
${ }^{13}$ This is, of course, standard professional practice for labor economists estimating the rate of return to education and experience from Mincer earnings functions. Excluding the self-employed, for example, has a practical econometric tradeoff; to the extent that the self-employed have different unmeasured characteristics, excluding them introduces a sample selection bias, but also removes returns to physical and financial capital from reported earnings.

${ }^{14}$ For occupational mobility, see Akresh (2006, 2008), Chiswick (1978b), Chiswick, Lee, and Miller (2005), Chiswick and Miller (2008, 2009), Green (1999), Jasso and Rosenzweig (1990a, 1995), and Zorlu (2013). For educational investment see, for instance, Duleep and Regets (1999), Chiswick and DebBurman (2004), Van Tubergen and van de Werfhorst (2007), and Jasso and Rosenzweig (1990a).

${ }^{15}$ Both analyses of Part V include the self-employed and the second analysis includes all individuals irrespective of labor force status.

${ }^{16}$ Lofstrom (2002) finds that including the self-employed reduces the immigrant-native earnings gap by $14 \%$.
} 
year-of-entry cohort, following only cohorts for which we have information on initial earnings, allowing educational attainment to grow (by not controlling for educational attainment), not excluding zero earners and the self-employed - we follow across decennial censuses the earnings of immigrant men who were in the entry cohorts of the great immigrant earnings' decline. If the primary force behind the post-1960 decline in immigrants' entry earnings was a decrease in the proportion of U.S. immigrants with skills that immediately transfer to the U.S. labor market then, according to a human-capital-investment perspective, each decline in immigrant entry earnings should be accompanied by an increase in earnings growth. If, on the other hand, the primary force behind the post-1960 decline in immigrants' entry earnings was a decline in immigrant labor market quality then each decline in immigrant entry earnings should be accompanied by either lower earnings growth or no change in earnings growth.

Removing the usual assumptions that underlie most estimations of immigrant earnings unveils an extraordinary picture (solid lines of Figure 1). As immigrants' entry earnings decreased over time, their earnings growth increased to such an extent that by the time of the subsequent census, ten years later, the earnings of the more recent cohort equals the relative earnings that earlier cohorts had achieved after 10 years. For instance, despite a 23.4 percent drop in the initial earnings relative to natives between the 1965-1970 and the 1975-1980 immigrant entry cohorts, their relative earnings by the time of the subsequent decennial census are 85 percent (in 1980) for the 1965-1970 cohort and 84 percent (in 1990) for the 1975-1980 cohort. The convergence occurs because the more recent cohort, with lower relative entry earnings, had much higher earnings growth.

A radically different picture emerges when we impose a trademark of the dummy-variable cohort methodology - the assumption of inter-cohort constancy in earnings growth. By estimating a model in which year-of-entry cohort effects are measured with year-of-entry dummy variables, cohort entry earnings are accurately portrayed. However, since the predicted earnings growth of the 1985-90 cohort is an average of the earnings growth rates of all three year-of-entry cohorts, its estimated earnings growth is far below its true earnings growth, as shown with a broken line in Figure 1.

Using the dummy-variable cohort methodology to measure whether earnings convergence occurs across source-country groups (the focus of Part V) is also problematic to the extent that changes occurred over time in the age- and education-adjusted earning trajectories of immigrants from specific countries. ${ }^{17}$ Convergence will be underestimated if recent country-specific cohorts with low initial earnings (relative to recent cohorts of other country-of-origin groups) were preceded by cohorts (from the same country of origin) with higher entry earnings and recent country-specific cohorts with high initial earnings (relative to recent cohorts of other country-of-origin groups) were preceded by cohorts with lower entry earnings. Convergence will be overestimated with the dummy-variable cohort methodology to the extent that recent cohorts with relatively low initial earnings (compared with recent cohorts of other country-of-origin groups) were preceded by cohorts with lower entry earnings and recent cohorts with relatively high initial earnings were preceded by cohorts with higher entry earnings.

In Part V, we allow earnings growth to vary with initial earnings by separately analyzing each year-of-entry cohort and following only cohorts for which we have information on initial earnings.

\footnotetext{
${ }^{17}$ Such changes could stem from a variety of causes including the relaxation of immigration restrictions, the post-1965 emphasis on family admissions, changes in the macro-economies of the sending and receiving countries, and over time changes in the economic development of the source country relative to the host country.
} 


\section{MEASURING THE IMPORTANCE OF COUNTRY OF ORIGIN AS A DETERMINANT OF IMMIGRANT EARNINGS}

Whether country-of-origin influences increase, decrease, or stay constant with time in the United States depends upon their underlying causes. If they primarily reflect intergroup differences in immigrant skill transferability, then earnings differences should narrow:

low-skill-transferability immigrants - immigrants whose source-country skills initially transfer poorly to the U.S. labor market and who thus have lower initial earnings - will have higher earnings growth, than high-skill-transferability immigrants. If country-of-origin effects primarily reflect the selection of more or less able individuals then such influences will persist or even grow in importance with time in the United States since low (high) ability likely dampens (increases) earnings growth; individual ability affects both the workplace productivity associated with a given level of human capital and an individual's ability to gain new human capital. In addition, as immigrants spend time in the United States, their different individual success rates would increase within-country variance in earnings. This, in and of itself, would lead to an increase with U.S. residence in the importance of country of origin as a determinant of immigrant earnings.

Key evidence that country-of-origin effects diminish comes from Chiswick (1978a, 1979), who discovered that U.S. immigrants from non-English-speaking countries had lower initial earnings but higher earnings growth than immigrants from English-speaking countries. Chiswick's seminal research was based on 1970 census data. However, as introduced and empirically tested in Chiswick (1980), inter-cohort changes in unmeasured immigrant quality may produce biased estimates of immigrant earnings growth in analyses based on a single cross-section. Following cohorts of immigrants provides a potential solution to the cross-sectional bias problem, as long as both entry earnings and earnings growth are allowed to vary. ${ }^{18}$

To shed further empirical light on whether country-of-origin influences diminish with time in the United States, we pursue two complementary cohort analyses. The first examines the relationship between the importance of country of origin, as a determinant of immigrant earnings, and immigrant time in the United States. The second examines whether the dispersion of earnings of demographically comparable immigrants, across different source countries, decreases over time. These analyses test three empirical implications of the skill-transferability explanation for country-of-origin differences in immigrant earnings: (1) earnings-related characteristics other than country of origin, such as years of schooling and experience, should become better predictors of immigrant earnings with time in the United States; (2) the importance of country of origin as a determinant of immigrant earnings should fade with residence in the United States; and (3) the earnings of demographically comparable immigrants, regardless of origin, should converge over time.

\section{Measuring the Explanatory Value of Country of Origin at Entry and Ten Years Later}

The skills transferability explanation for intergroup differences in the initial education- and age-adjusted earnings of immigrants predicts that as immigrants with low skill transferability invest more heavily in U.S. human capital, than immigrants with high skill transferability, the importance of country of origin as a determinant of immigrant earnings will decrease while the importance of other earnings-related characteristics will increase. To determine how the importance of country of origin as a determinant of immigrant earnings changes with immigrant time in the United States, we estimated two log earnings regressions, shown below, for various immigrant entry cohorts using the

\footnotetext{
${ }^{18}$ Because of the inverse relationship between entry earnings and earnings growth, in cases where immigrant entry earnings have been falling over time, cross-sectional estimation will overestimate the earnings growth of earlier year-of-entry cohorts while producing more accurate estimates than the dummy-variable cohort methodology of the earnings growth of the recent immigrant cohorts.
} 
Public Use Micro Samples (PUMS) from the 1960, 1970, and 1980 censuses. ${ }^{19}$

The first earnings regression — the basic human capital model—includes years of schooling, years of work experience, and experience squared as regressors. ${ }^{20}$ This earnings function was purposely kept sparse to allow other differences in productivity to be captured by country-of-origin variables in a second model, which added to the base set of regressors a set of dummy variables denoting an individual immigrant's country or region of origin, both alone and interacted with the education and experience variables. Including interactions with education and experience allows country of origin to add explanatory power through country-of-origin differences in the value of education and experience, as well as through differences in the regression intercept.

human capital model: $\quad \log \mathrm{y}_{\mathrm{it}}=\alpha+\beta_{1} \mathrm{Ed}_{\mathrm{it}}+\beta_{2} \operatorname{Exp}_{\mathrm{it}}+\beta_{3} \operatorname{Exp}_{\mathrm{it}}^{2}+\varepsilon_{\mathrm{it}}$ human capital model with country-of-origin variables:

$\log y_{i t}=\alpha+\beta_{1} \operatorname{Ed}_{i t}+\beta_{2} \operatorname{Exp}_{i t}+\beta_{3} \operatorname{Exp}_{\text {it }}^{2}+\gamma_{1} G_{i}+\gamma_{2} G_{i} \cdot \operatorname{Ed}_{i t}+\gamma_{3} G_{i} \cdot \operatorname{Exp}_{i t}+\gamma_{4} G_{i} \cdot \operatorname{Exp}_{i t}^{2}+\varepsilon_{i t}$ where $y_{i t}=$ the earnings of individual $\mathrm{i}$ in year $\mathrm{t}$; $\mathrm{Ed}=$ years of schooling; Exp = age minus years of schooling minus 6 ; and $\mathrm{G}_{\mathrm{ji}}=$ a categorical variable denoting the source country $\mathrm{j}$ (or country-group j) of immigrant $i$.

The above pair of earnings regressions was first estimated for a cohort of immigrant men, aged 25-54, who had only been in the United States 0-5 years. (The cohort that had entered the United States during the 5 years prior to a decennial census.) Using the subsequent decennial census, we estimated the same pair of earnings equations, for the same cohort, 10 years later and aged 35-64. We could thus compare for each cohort the extent to which adding country of origin increased the explanatory value of the earnings regression at time of entry and 10 years later, as measured by R-squared. ${ }^{21}$

${ }^{19}$ We used the 1980 5\% "A" PUMS, the 1970 1\% State PUMS based on the 5\% questionnaire, and the $19601 \%$ PUMS (Bureau of the Census, 1983, 1977, and 1975). The 1960 census did not collect year-of-immigration information; place of residence in 1955 permits us to identify immigrants who entered the U.S. between 1955 and 1960.

${ }^{20}$ We limit our focus to annual earnings. No information is provided in any census on wages per se. Although information on hours and weeks worked is available in the 1980 census, it is only recorded in broad brackets in the 1960 and 1970 censuses.

${ }^{21}$ It is often suggested that we use $\overline{\mathrm{R}}^{2}$ versus $\mathrm{R}^{2}$ in this analysis. Theoretically $\mathrm{R}^{2}$ is the correct measure since it measures the portion of the variance accounted for by a model's variables and coefficients. $\bar{R}^{2}$ is useful for choosing between model specifications as it adjusts for the model's number of explanatory variables relative to the number of data points the model is estimated on, decreasing with the addition of explanatory variables that improve the model by less than expected by chance. This adjustment, however, means that we cannot interpret a change in $\overline{\mathrm{R}}^{2}$, with the addition of the country variables, as the real increase in explanatory power. (We cannot interpret the difference in $\overline{\mathrm{R}}^{2}$ after adding the country variables as the increase in explanatory power of the source-country variables minus the increase in explanatory power from adding the same number of random variables.) Differences in $\mathrm{R}^{2}$ are more relevant than differences in $\overline{\mathrm{R}}^{2}$ for our analysis, even if some portion of the change in explanatory power is due to chance. Moreover, in each case we add the same number of country variables to the model, reducing degrees of freedom by the same number of points. To the extent that this results in a roughly similar increase in $\mathrm{R}^{2}$ by chance, the proportional change in the explanatory power of the country variables overtime will be understated, not overstated.

Empirically, it doesn't matter whether we use $\mathrm{R}^{2}$ or $\overline{\mathrm{R}}^{2}$. For the cohorts examined in Table 7-with the sample size for each cohort exceeding 30,000 observations- $R^{2}$ or $\bar{R}^{2}$ are nearly identical, differing only after the first two or three digits following the decimal point. Smaller sample sizes characterize the earlier cohorts of Table 2: There are 2,665 observations for the 1955-59 cohort in 1960 and 2,168 in 1970; 3,577 observations for the 1965-69 cohort in 1970 and 17,683 in 1980. To assuage any concerns, the results for Table 2 in terms of $\overline{\mathrm{R}}^{2}$ are shown below.

\begin{tabular}{|l|c|c|c|c|}
\hline Entry Cohort, Census year & $\begin{array}{l}\mathrm{R}^{2} \text { for human } \\
\text { capital model }\end{array}$ & $\begin{array}{l}\mathrm{R}^{2} \text { for } \mathrm{HC} \text { model } \\
\text { with country } \\
\text { variables }\end{array}$ & $\begin{array}{l}\text { Change in } \mathrm{R}^{2} \\
\text { from adding } \\
\text { country variables }\end{array}$ & $\begin{array}{l}\text { Percentage change } \\
\text { in } \mathrm{R}^{2} \text { from adding } \\
\text { country variables }\end{array}$ \\
\hline $1955-59,1960$ & .1144 & .2531 & .1387 & 121.2 \\
\hline $1955-59,1970$ & .1594 & .2202 & .0608 & 38.1 \\
\hline $1965-69,1970$ & .0805 & .1540 & .0735 & 91.30 \\
\hline $1965-69,1980$ & .1662 & .2029 & .0367 & 22.08 \\
\hline
\end{tabular}


The results from this analysis following the 1955-59 and 1965-69 cohorts are shown in Table 2. ${ }^{22}$ We see for each cohort that the $\mathrm{R}^{2}$ for the base regression increases with the passage of ten years. Since we limit our sample for each regression to those who entered the United States during the same 5-year period, but whose ages span 30 years, most of the variation in experience in the sample occurs before migration. Since we start with 25 -year-olds, much of the variation in education reflects education outside of the United States. ${ }^{23}$ The same holds true for the ten-year-after regressions: although individuals now may have substantial U.S. experience, there is little additional variation in the amount of U.S. experience in the sample. Thus the $\mathrm{R}^{2}$ for the base model primarily measures the explanatory power of country-of-origin human capital; its increase over time is consistent with an increase in the value of country-of-origin human capital over time, as it both complements and aids in the acquisition of new U.S. skills.

Country-of-origin effects over time can be seen more directly from the fourth and fifth columns where both the absolute and relative gain in $\mathrm{R}^{2}$ from adding country of origin is dramatically smaller ten years after our initial observations for each cohort. This suggests that the importance of country of origin as a determinant of immigrant earnings for a given cohort decreases with immigrant time in the United States.

\section{Do the changes in $\boldsymbol{R}^{2}$ reflect other processes?}

Quite apart from our hypothesis of immigrant earnings convergence, unexplained earnings variation will change over the life cycle, and in different economic environments. Since the early 1970's, earnings dispersion has increased due to differences in the return to observed (and, it is often theorized, unobserved) human capital. In addition younger workers' observed earnings (as opposed to potential earnings) will vary in part due to greater variation in the proportion of earnings foregone due to human capital investment, while older workers' earnings will vary in part due to greater variation in the stock of human capital. To what extent do the changes in $\mathrm{R}^{2}$ for each cohort reflect an immigrant phenomenon conforming to the skills transferability hypothesis versus the change in age range from the first to the second period, or the over-time change in the earnings distribution? The sensitivity of our analyses to these life-cycle and period effects may be partially tested by examining the changes in $\mathrm{R}^{2}$ that occur following a cohort of U.S.-born men. ${ }^{24}$

Table 2a shows little change in the explanatory power of the basic human capital model for native male cohorts followed between 1960 and 1970, and between 1970 and 1980. Going from 1960 to $1970, \mathrm{R}^{2}$ rose for natives, but by a much smaller amount than for the 1955-59 entry-cohort immigrants (Table 2). Going from 1970 to 1980 , the base model $\mathrm{R}^{2}$ for natives fell slightly, while the base model $\mathrm{R}^{2}$ for the 1965-69 entry-cohort immigrants more than doubled. Consistent with initial differences in skill transferability, the initial base-model $\mathrm{R}^{2}$ for the entry-cohort immigrants is lower than for natives in both 1960 and 1970; ten years later, it is somewhat greater for immigrants than for natives in both periods.

\section{Measuring Earnings Dispersion at Entry and Ten Years Later}

We also test whether the earnings differences of demographically comparable immigrants by country of origin narrow with years since migration. To do this, we examine the degree of dispersion in the median earnings of immigrant men by country of origin within age/education cells for cohorts that had entered the United States during the five years prior to a decennial census, and again ten years later. Median earnings were measured within education and age subsets for 27

\footnotetext{
${ }^{22}$ Full regression results are available from the authors.

${ }^{23}$ We use the term "much" but not "all" advisedly: among persons 25 years old and older, Duleep and Regets (1999) find higher rates of school attendance for recent immigrants than for natives.

${ }^{24}$ It is not, of course, possible to use country-of-origin dummies with natives.
} 
countries, cell sample sizes permitting. ${ }^{25}$ We chose the coefficient of variation, defined in this case as $\sigma /\left|\overline{\mathbf{x}}_{\text {med }}\right|$ (the standard deviation of the distribution of median earnings divided by the mean of the distribution of median earnings) as our measure of dispersion since this measures dispersion in relation to mean earnings, which grew substantially in both real and nominal terms over the 1960's and 1970's. ${ }^{26}$ All 8 cohort comparisons, shown in Table 3, reveal important reductions in the coefficient of variation $(\mathrm{CV})$ after ten years: within age and education groups, the across-source-country earnings variation declines by 13 to 55 percent.

As with the previous analysis using $\mathrm{R}^{2}$, we explore the sensitivity of this analysis to intra-cohort changes in age distribution and census-year earnings distributions by following an age cohort of U.S.-born men between the 1960 and 1970 censuses, and between the 1970 and 1980 censuses. The coefficient of variation in earnings for U.S. natives ${ }^{27}$ is shown in Table 3 a for the four age/education cells used in Table 3. While the CV of earnings for recent immigrants declined over time in each case, it increased in most cases for native males. The major exceptions are the group of younger, high-education natives, whose earnings CV shows large declines in both periods, and the group of older, high-education natives in the 1960-1970 period, who experienced a small decline. Yet, even in those cases, the percentage decline in the earnings CV for immigrants greatly exceeds that for natives.

\section{EMIGRATION BIAS AND THE DECLINE IN THE IMPORTANCE OF COUNTRY OF ORIGIN}

Since our findings are based on analyses that follow samples of individuals, across decennial censuses, rather than the same individuals, careful thought must be given to potential biases caused by immigrants leaving the United States. ${ }^{28}$ Does the country-of-origin earnings convergence reflect selective emigration systematically related to the U.S. earnings of immigrants?

The type of selection bias of earnings growth caused by emigration, and even the extent of U.S. emigration, are hotly contested issues in immigration research. ${ }^{29}$ One continuing theme with

\footnotetext{
${ }^{25}$ Sample size concerns led us to group many countries, and to group age and education each into two categories. Also, any estimate of median earnings based on a sample size of less than 5 individuals was dropped. The education categories are 1-12 years and 13 or more years. The age categories are 25-39 and 40-54 for entry cohorts on the 1960 and 1970 PUMS, and 35-49 and 50-64 for the same cohorts ten years later on the 1970 and 1980 PUMS. The source-country/region selection is kept constant across all of the analyses in this paper, so that the results are not affected by changes in how the source countries/regions were defined. We also did several sensitivity tests and found very similar results regardless of how the source country/regions were defined. The source countries/regions used in the analyses are: Africa, Britain, Canada, China/Taiwan, Cuba, Czechoslovakia, Germany, Greece, Hungary, India, Ireland, Islamic Southwest Asia, Italy, Jamaica, Japan, Korea, Mexico, Oceania, Other Asia, Other Central America, Other Communist Europe, Other Non-Communist Europe, Philippines, Poland, Portugal, South America, and Yugoslavia. Census-based codes to create the multi-country groups are available from the authors.

${ }^{\mathbf{2 6}}$ Estimates of standard errors for our estimates of the coefficient of variation follow Kakwani (1990) in which the standard error of a coefficient of variation on a variable $X$ is given by: $\sigma_{c v}=\left(\left(\left(M^{2}\left(M_{4}-M_{2}^{2}\right)+4 M_{2}\left(M_{2}^{2}-\left(M_{3}\right)\right)\right) /\right.\right.$ $\left.\left(16 \mathrm{M}^{4}\left(\mathrm{M}_{2}-\mathrm{M}^{2}\right)\right)\right)^{0.5}$ where $\mathrm{M}$ is the mean of $\mathrm{X}, \mathrm{M}_{2}$ is the mean of $\mathrm{X}^{2}, \mathrm{M}_{3}$ is the mean of $\mathrm{X}^{3}$, and $\mathrm{M}_{4}$ is the mean of $\mathrm{X}^{4}$. In computing the coefficient of variation, each median earnings observation was weighted by the number of individuals in the age/education/country-of-origin category in the starting period.

${ }^{27}$ The coefficient of variation in individual earnings is a slightly different concept than that of the CV of median earnings of country-of-origin groups. This alternative measure was used since native males could not be grouped by source country. Although individual earnings show greater total variation, our focus is on how this variation changes over time as a cohort ages, and between time periods.

${ }^{28}$ During the period 1908-1950, the U.S. government collected annual statistics on those who left the United States. Using this record of information, Warren and Kraly (1985) estimated that about 75 percent of the immigrants who emigrated during this period did so in their first 5 years of U.S. residence. The analysis of more recent evidence confirms that most immigrants who emigrate do so within their first five years of residence (Duleep, 1994).

${ }^{29}$ Reviews of emigration studies include Lalonde and Topel (1997) and Dustmann and Görlach (2014)
} 
early roots is that it is the less successful, relative to immigrants with the same age, education and country of origin, who are most likely to emigrate. ${ }^{30}$ In this case, earnings growth estimates based on following immigrant cohorts are biased upwards, since lower earning individuals would not be in the sample for later censuses. Another continuing theme, also with early roots, suggests the reverse. Chiswick failed to find evidence that, controlling for education, the unsuccessful are more likely to emigrate: "If anything, re-emigration rates are higher the greater the transferability of skills and if the original migration is economic in nature" (Chiswick, 1980, p. 4A-17). ${ }^{31}$ Despite the opposing predictions, these models (and their descendants in more recent literature) share a common trait: emigration occurs most frequently in the same part of the earnings distribution for each country-of-origin immigrant group, regardless of the group's place in the overall earnings distribution.

In other models, the distribution of emigration within each country-of-origin group is affected by its place in the overall earnings distribution. One emigration-earnings relationship suggests that immigrants from countries with less equal income distributions than the United States would (controlling for education and age) tend to have relatively low U.S. earnings; within those groups, the higher the earnings ability of immigrants, the less they would benefit from living in the U.S. relative to living in their country of origin, and the more likely they would be to emigrate. Immigrants from countries with more equal income distributions than the United States would have relatively high earnings on average; within those groups, the lower the earnings ability of immigrants, the less they would benefit from living in the U.S. relative to living in their country of origin, and the more likely they would be to emigrate.

Given this diversity of perspectives - with opposing conclusions - and the fact that there are other etiologies, ${ }^{32}$ we pursue two tests to assess the sensitivity of our convergence results to emigration, without embracing any one assumption about the nature of the emigration-earnings relationship. By exploiting the differential relationship that exists between hypothetical emigration patterns and our two analyses of earnings convergence, we first gauge theoretically how potential patterns of emigration, as a function of the U.S. earnings of immigrants, would affect the results of Section V. We then examine emigration bias empirically, re-estimating the two earnings convergence analyses on samples of high- and low-emigration countries.

\section{A Theoretical Approach for Assessing the Impact of Emigration}

Potential patterns of emigration as a function of the U.S. earnings of immigrants are shown in Figure 2. The series of distributions shown in panels A and B represent hypothetical distributions of U.S. immigrant earnings from particular countries of origin with $\bar{Y}$ denoting the average earnings of immigrants across all countries of origin. The darkened areas indicate where in each country-of-origin earnings distribution emigration is most likely to occur.

In Panel A, emigration occurs most frequently in the same part of the earnings distribution for each country-of-origin immigrant group, regardless of the group's place in the overall earnings distribution. In the specific example shown, low earners in each country-of-origin immigrant group are more likely to emigrate. This model might fit particularly well if the original decision to immigrate was based in part on knowledge of how fellow countrymen with similar levels of education and experience had fared in the United States. Those in the lower end of the distribution,

\footnotetext{
${ }^{30}$ Yezer and Thurston (1976) proposed this theory in a study of U.S. migration. Other early studies with the prediction that it is the unsuccessful who migrate include Vanderkamp (1972) and DaVanzo (1983). Underscoring the complexity of emigration, DaVanzo(1983, p. 558) notes possible interactions between who emigrates and the timing of emigration: "Only those migrants who return promptly...conform to the "failure' stereotype..." Also see Davanzo (1976) and DaVanzo and Morrison (1981).

${ }^{31}$ Also see Jasso and Rosenzweig (1990a).

${ }^{32}$ See, for instance, Dustmann (2000) and Cortes (2004).
} 
who did worse in the job market than they had originally expected, would be the most likely to emigrate. Such a pattern would reduce the dispersion within each country-of-origin group. As a result of emigration, the relative contribution of country of origin to explaining earnings, as measured by the change in $\mathrm{R}^{2}$, would increase. This would lead us to underestimate in our first convergence analysis the decline in the importance of country of origin with immigrant time in the United States. ${ }^{33}$ But, since the propensity to emigrate is similarly distributed across all countries, this type of emigration does not pose a problem for our second convergence analysis as it affects only the within-country earnings variance, not the dispersion of median earnings across all countries.

Another variation of Panel A is emigration of the high earners in the right tail of each group's distribution. This has exactly the same effect on our two measures of convergence as emigration from the left tail: the reduction in the dispersion of earnings within each country-of-origin group will cause an overestimate of the importance of country of origin with immigrant time in the U.S., but no change in the dispersion of median earnings.

Finally, consider emigration in the center of each country-of-origin group's earning distribution. While still having no effect on the dispersion of median earnings, this will increase the dispersion of earnings within each country-of-origin group. This scenario is of particular concern to our first analysis of convergence since it would lead us to underestimate the importance of country of origin with immigrant time in the United States and thus overstate the decline in its importance.

Panel B shows a different pattern of emigration in which the distribution of emigration within each country-of-origin group is affected by its place in the overall earnings distribution: emigration is more likely among low-earning immigrants from country-of-origin groups with high median earnings and high-earning immigrants from country-of-origin groups with low median earnings. The reverse case can also be considered: high earners from high-earning countries and low earners from low-earning countries are more likely to emigrate. Both scenarios would reduce the dispersion of earnings within the country-of-origin groups. In our first convergence analysis of the change in $\mathrm{R}^{2}$, emigration would lead us to overestimate the importance of country of origin with immigrant time in the U.S., and thereby underestimate the decline in its importance. In our second analysis, these two scenarios would have opposite effects: emigration increases the dispersion of median earnings leading to an underestimate of convergence. The second scenario is of greater concern since it would lead us to overestimate convergence.

The potential biases in our two convergence analyses caused by each stylized pattern of emigration are summarized in Table 4; a plus sign indicates emigration patterns that would cause us to overstate convergence. For each pattern of emigration, at least one of our two analyses measuring earnings convergence is either unaffected, or is biased in such a way to understate earnings convergence. Thus while each of our analyses could produce a spurious convergence due to emigration, none of the theoretical emigration patterns would overstate convergence in both analyses.

\section{An Empirical Approach for Assessing the Impact of Emigration}

To empirically examine the effect of emigration bias, we re-estimated our two convergence analyses dividing the sample into high- and low-emigration source-country groups. If our findings

\footnotetext{
${ }^{33}$ In the first convergence analysis we compute $\mathrm{R}_{\mathrm{w}}^{2}-\mathrm{R}^{2}{ }_{\mathrm{wo}}$ or $\left[1-\Sigma\left(\mathrm{y}_{\mathrm{i}}-\hat{y}_{\mathrm{iw}}\right)^{2} / \Sigma\left(\mathrm{y}_{\mathrm{i}}-\overline{\mathrm{y}}\right)^{2}\right]-\left[1-\Sigma\left(\mathrm{y}_{\mathrm{i}}-\hat{y}_{\mathrm{iwo}}\right)^{2} / \Sigma\left(\mathrm{y}_{\mathrm{i}}-\overline{\mathrm{y}}\right)^{2}\right]$ for entering immigrants and for the same cohort 10 years later, where $\hat{y}_{i w}$ is the predicted earnings of individual i from the equation with country of origin and $\hat{y}_{\text {iwo }}$ is the predicted earnings of individual $i$ from the equation without country of origin. Emigration at the tails of the country-of-origin earnings distributions will cause $\mathrm{y}_{\mathrm{i}}$ to be more closely distributed around $\hat{y}_{\mathrm{iw}}$, relative to $\hat{y}_{\mathrm{iwo}}$, and $\mathrm{R}_{\mathrm{w}}^{2}-\mathrm{R}_{\text {wo }}^{2}$ to become larger; emigration at the center of the country-of-origin earnings distributions will have the reverse effect.
} 
of convergence solely reflect emigration, we should consistently find greater convergence in country-of-origin cohorts with high emigration. Re-estimating our analyses on samples divided by emigration level also allows us to determine whether our findings of convergence persist when emigration variation is reduced.

Our measure of 10-year emigration is calculated using the number of observations for each cohort on the 1960-80 decennial censuses adjusted to the 5 percent sampling proportion of the 1980 census file. Since sample sizes and census coverage changes over time make this a crude measure, we use it only to categorize the country-of-origin cohorts as having high or low emigration rates, with the median emigration rate serving as the dividing point.

Table 5 shows our findings when we re-estimate the explanatory power of country of origin over high- and low-emigration samples. For both high and low emigration country-of-origin groups, the addition of country of origin adds less to the explanatory power of the earnings regression after a cohort has been in the United States 10 years. Most importantly, the magnitude of the effects seem unrelated to high or low emigration.

Estimates of the dispersion of median earnings for high and low emigration samples are shown in Table 6. Not surprisingly, there is more variability in the estimates given the decrease in the cell sample sizes after dividing the sample. Nevertheless, in all eight age/education/entry-year cohorts, the coefficient of variation decreases in the ten years between decennial censuses, and no strong pattern emerges of larger (or smaller) reductions in earnings variation for the high-emigration cohorts.

\section{MORE RECENT EVIDENCE}

Part V used 1960-1980 census data to focus on the immigrant cohorts immediately before and after the Immigration and Nationality Act of 1965, when the earnings of entering immigrants went from equaling to being vastly below U.S. natives' earnings. To determine whether convergence continued for subsequent cohorts of U.S. immigrants, we repeated the analyses of Tables 2 and 3 with more recent census data. ${ }^{34}$

Using 1980-2000 decennial census data, Table 7 shows for the 1975-80 and 1985-90 cohorts the extent to which adding country of origin increases the explanatory value of the earnings regression at time of entry and 10 years later, as measured by R-squared. Following our earlier framework, we estimate a pair of earnings regressions at entry, and ten years later. The first earnings regression in the pair includes as regressors level of schooling ${ }^{35}$ and age and age squared (as proxies for years of work experience and experience squared). ${ }^{36}$ The second earnings regression adds to the human capital model a set of dummy variables denoting an individual immigrant's country or region of origin, both alone and interacted with the education and

\footnotetext{
${ }^{34}$ We used three datasets: a 1980 5\% "A" PUMS, a $6 \%$ microdata sample created by combining and reweighting the 1990 5\% and 1\% PUMS, and a 2000 combined 5\% and 1\% PUMS (Bureau of the Census, 1983, 1992, 2008).

${ }^{35}$ Although the 1980 census data have years of schooling, information on schooling achievement in the 1990 data is in categories. To maintain conformity in the explanatory-variable definitions across censuses, we included five dummy variables for schooling categories in both the 1980 and 1990 earnings regressions: 9-11 years, high school degree, some college (including two-year degrees), Bachelor's degree, and graduate degree, for the 1990 census and 9-11 years, 12 years, 13-15 years, 16-17 years, and 18 years or more, for the 1980 census. The excluded variable in both specifications is eighth grade or less. Another complication is that the 1990 census definition measures successful completion of various schooling levels whereas the 1980 definition measures years of completed schooling per se. Analysis of a sample from the Current Population Survey with both the new and old census education questions revealed that 17 years of schooling was most consistent with completion of only a bachelor's degree (Jaeger, 1997 , Jaeger and Page, 1996).

${ }^{36}$ For the 1980-1990 analysis, age rather than age minus years of schooling minus 6 was used for both periods for consistency. (See the previous note on the 1980-1990 changes in education measurement.)
} 
experience variables. We find, as before, that the $\mathrm{R}^{2}$ for the human capital regression increases with the passage of ten years, consistent with the hypothesis that schooling and experience become better predictors of immigrant earnings with time in the United States. Concomitantly, both the absolute and relative gain in $\mathrm{R}^{2}$ from adding country of origin is dramatically smaller ten years after our initial observations.

Table 8 examines whether earnings convergence occurs across immigrant source-country groups. Confirming our previous results, all of the cohort comparisons delineated by age and education show reductions in the coefficient of variation $(\mathrm{CV})$ after ten years. ${ }^{37}$

\section{CONCLUSION}

We examine how the well-documented importance of country of origin to immigrant earnings changes with time in the United States. Our first analysis reveals a decrease in the explanatory power with time in the United States of country-of-origin variables in earnings regressions estimated across individuals in specific year-of-entry immigrant cohorts. This suggests that the importance of country of origin for explaining earnings decreases as immigrants stay in the United States. Our second analysis reveals a decrease with time in the United States in the dispersion of individual earnings across country of origin within various age/education/year-of-entry cohorts. This suggests that the earnings of demographically comparable immigrants, regardless of origin, tend to converge over time.

As the analyses are based on following cohort samples, emigration is a serious concern. However, theoretical emigration patterns that would cause a spurious decrease in the importance of country of origin in one analysis are the complement of the emigration patterns that would cause a spurious decrease in the other analysis. Moreover, using a technique that could be applied more generally, both results persist in an empirical test of emigration bias.

The convergence results do not appear to be the result of other processes such as labor-market-wide changes in earnings distribution between censuses or to earnings distribution changes that occur, in general, as individuals gain experience. Similar natives over the same periods do not show similar declines in earnings variation, and the importance of the basic human capital model to explain that variation does not change importantly for U.S.-born cohorts over these periods.

Taken as a whole, our analyses suggest that although country of origin plays a prominent role in determining the entry-level earnings of immigrants, its importance decreases with time in the United States. This conclusion is consistent with other research that predicts or finds an inverse relationship, conditional on initial immigrant education levels, between immigrant entry earnings and earnings growth. ${ }^{38}$

The convergence has methodological implications for the measurement of immigrant economic assimilation. In the presence of an inverse relationship between immigrant entry earnings and earnings growth, a methodology that permits entry earnings but not earnings growth to vary misinforms as much, if not more, than a methodology that assumes stationarity in both entry earnings and earnings growth (the cross-sectional methodology). In the presence of an inverse

\footnotetext{
${ }^{37}$ As in the previous analyses on earlier cohorts, we test the sensitivity of our results to intra-cohort changes in age distribution and census-year earnings distributions by following an age cohort of U.S.-born men between the 1980 and 1990 censuses and between the 1990 and 2000 censuses. The results echo the results of Tables 2A and 3A. For instance, for the 25-54 age cohort, the base model $\mathrm{R}^{2}$ in 1980 is .1185 and .1161 in 1990. Going from 1990 to 2000, the base model $\mathrm{R}^{2}$ for natives fell (.1563 in 1990 and .1222 in 2000).

${ }^{38}$ Examples include Chiswick (1978a, 1979), Lalonde and Topel (1991, 1997), Duleep and Regets (1994, 1996a, b; 1997a, b; 1999; 2002), Schoeni (1997), Demombynes (2002), Akresh (2007), Green and Worswick (2012), and Lin (2013).
} 
relationship, it is as nonsensical to let entry earnings vary, but not earnings growth, as it would be to let earnings growth vary, but not entry earnings. The importance of letting both entry earnings and earnings growth vary holds whether the analyst's focus is all immigrants, or a subset of immigrants. Because of the large sample sizes and numerous variables, decennial census data will continue to illuminate the over-time transitions of immigrant subgroups. Adopting methodologies that permit both entry earnings and earnings growth to vary, as we have done, is critical in studies that follow cohorts across decennial censuses. It is equally critical for studies that follow individuals with longitudinal data. More generally, it pertains to the analysis of any process in which unmeasured variables jointly affect initial conditions and subsequent growth. 


\section{References}

Akresh, Ilana R. 2006. "Occupational Mobility among Legal Immigrants to the United States." International Migration Review, 40(4):854-884.

—, 2007. 'U.S. Immigrants' Labor Market Adjustment: Additional Human Capital Investment and Earnings Growth." Demography, 44(4):865-881.

-, 2008. Occupational Trajectories of Legal U.S. immigrants: Downgrading and Recovery. Population and Development Review 34 (3):435-456.

Andersson, Fredrik, Mónica García-Pérez, John Haltiwanger, Kristin McCue, and Seth Sanders, 2010. "Workplace Concentration of Immigrants," NBER Working Paper No. 16544.

Angrist, Joshua and Adriana Kugler. 2003. "Protective or Counter-Productive? Labor Market Institutions and the Effect of Immigration on EU Natives," The Economic Journal, 113(488):302-331.

Bailey, Thomas R., 1987. Immigrant and Native Workers: Contrasts and Competition, Boulder and London: Westview Press.

Barrett, Alan, Seamus McGuinness, Martin O'Brien, and Philip O'Connell, 2013. "Immigrants and Employer-Provided Training." Journal of Labor Research. 34 (1):52-78.

Bauer, Thomas, Pereira, P Pedro Pereira, Michael Vogler, and Klaus Zimmermann, 2002. "Portuguese Migrants in the German Labor Market: Performance and Self-Selection" International Migration Review. 36(2):467-491.

Bauer, Thomas, Gil Epstein, and Ira Gang, 2005. "Enclaves, Language and the Location Choice of Migrants.” Journal of Population Economics, 18(4):649-662.

Bohn, Sarah and Seth Sanders, 2007. "Refining the Estimation of Immigration's Labor Market Effects," http://public.econ.duke.edu/ staff/wrkshop_papers/2007-08Papers/Sanders.pdf.

Bureau of the Census, 1975. A Public Use Sample of Basic Records from the 1960 Census: Description and Technical Documentation, Washington, D.C.: Bureau of the Census.

—, 1977. Public Use Samples of Basic Records from the 1970 Census: Description and Technical Documentation, Washington, D.C.: Bureau of the Census.

—, 1983. Census of Population and Housing, 1980: Public Use Microdata Samples, Technical Documentation, Washington, D.C.: Bureau of the Census.

- 1992. Census of Population and Housing 1990: Public Use Microdata Sample, Technical Documentation, Washington, DC: Bureau of the Census.

-, 2008. Census of Population and Housing 2000: Public Use Microdata Sample, Technical Documentation, Washington, DC: Bureau of the Census.

Chiswick, Barry, 1978a. "The Effect of Americanization on the Earnings of Foreign-Born Men," Journal of Political Economy, October 86(5):897-922.

—, 1978b. "A Longitudinal Analysis of Occupational Mobility of Immigrants," in ed. Barbara Dennis, Proceedings of the 30th Annual Winter Meeting, Industrial Relations Research Association, December, 1977, Madison, Wisconsin, 20-27.

—, 1979. "The Economic Progress of Immigrants: Some Apparently Universal Patterns," in W. Fellner, ed., Contemporary Economic Problems. Washington, D.C.: American Enterprise Institute:359-99.

-, 1980. An Analysis of the Economic Progress and Impact of Immigrants, Department of Labor monograph, N.T.I.S. No. PB80-200454. Washington, DC: National Technical Information Service.

Chiswick, Barry and Noyna DebBurman. 2004. "Educational Attainment: Analysis by Immigrant Generation," Economics of Education Review 23:361-379.

Chiswick, Barry, Yew Liang Lee, and Paul Miller, 2005. "Longitudinal Analysis of Immigrant Occupational Mobility: A Test of the Immigrant Assimilation Hypothesis." International Migration Review, 39 (2):332-353. 
Chiswick, Barry and Paul Miller, 2008. "Occupational Attainment and Immigrant Economic Progress in Australia," Economic Record, 84(S1):S45-S56

—, 2009. "Earnings and Occupational Attainment among Immigrants," Industrial Relations, 48(3):454 - 465

-, 1992. "Language in the Immigrant Labor Market" in ed. Barry Chiswick, Immigration, Language, and Ethnicity: Canada and the United States, Washington, DC: American Enterprise Institute, 229-296

Constant, Amelie and Klaus Zimmermann, 2014. "Self-Employment Against Employment or Unemployment: Markov Transitions Across the Business Cycle," Eurasian Business Review, 4:51-87.

Cortes, Kalena E., 2004. “Are Refugees Different From Economic Immigrants? Some Empirical Evidence on the Heterogeneity of Immigrant Groups in the United States." Review of Economics and Statistics. 86 (2):465-480.

DaVanzo, Julie, 1976. "Differences between Return and Non-Return Migration: An Econometric Analysis," International Migration Review, 10(1):13-27

—, 1983. "Repeat Migration in the United States: Who Moves Back and Who Moves On?," Review of Economics and Statistics, 65(4):552-559.

DaVanzo, Julie, and Peter A. Morrison, 1981. "Return and Other Sequences of Migration in the U.S.," Demography, 18(1):85-101.

DeFreitas, Gregory, 1991. Inequality at Work: Hispanics in the U.S. Labor Force, Oxford and New York: Oxford University Press.

—, 1993. "Unionization among Racial and Ethnic Minorities," Industrial and Labor Relations Review, 46(2):284-301.

Demombynes, Gabriel M., 2002. “Three Ways of Looking at Immigrant Wage Growth: Analysis with the 1993-1998 Current Population Survey" Institute for Labor and Employment Conference, January.

DeSilva, Arnold, 1996. "Earnings of Immigrant Classes in the Early 1980's in Canada: A Re-examination," Working Paper, Human Resource Development Canada.

Duleep, Harriet Orcutt, 1994. "Social Security and the Emigration of Immigrants," Social Security Bulletin, 57(1):37-52.

Duleep, Harriet and Daniel Dowhan, 2002. "Insights from Longitudinal Data on the Earnings Growth of U.S. Foreign- Born Men," Demography 39(3):485-506.

Duleep, Harriet and Mark Regets. 1994. "The Elusive Concept of Immigrant Quality: Evidence from 1960-1980," (1992 American Economic Association version), PRIP-UI-28, Washington, DC: Urban Institute.

—, 1996a. "Admission Criteria and Immigrant Earnings Profiles," International Migration Review, 30(2):571-90.

—, 1996b. "Family Unification, Siblings, and Skills" in H. Duleep and P. V. Wunnava (eds.), Immigrants and Immigration Policy: Individual Skills, Family Ties, and Group Identities, Greenwich, CT: JAI Press, 219-244.

—, 1997a. "Measuring Immigrant Wage Growth Using Matched CPS Files," Demography, 34(2):239-249.

—, 1997b. "Immigrant Entry Earnings and Human Capital Growth," Research in Labor Economics, 16:297-317.

—, 1997c. "The Decline in Immigrant Entry Earnings: Less Transferable Skills or Lower Ability?" Quarterly Review of Economics and Finance, 37(S1):189-208.

_, 1999. "Immigrants and Human Capital Investment," American Economic Review, 89(2):186-191

—, 2002. “The Elusive Concept of Immigrant Quality: Evidence from 1970-1990,” IZA Discussion Paper \#631, http://ftp.iza.org/dp631.pdf 
Dustmann, Christian, 2000. "Temporary Migration and Economic Assimilation." Swedish Economic Policy Review, 7 (2):213-244.

Dustmann, Christian and Joseph-Simon Görlach, 2014. "Selective Outmigration and the Estimation of Immigrants' Earnings Profiles.” Norface Discussion Paper Series, Norface Research Programme on Migration, Department of Economics, University College London.

Gallo, Carmenza and Thomas Bailey, "Social Networks and Skills-Based Immigration Policy," in H. Duleep and P. Wunnava, eds., Immigrants and Immigration Policy: Individual Skills, Family Ties, and Group Identities, Greenwich, CT: JAI Press, 1996.

Gang, Ira N. and Francisco L. Rivera-Batiz. 1994a. "Labor Market Effects of Immigration in the United States and Europe: Substitution vs. Complementarity," Journal of Population Economics, 7(2):157-175.

—, 1994b. "Unemployment and Attitudes toward Foreigners in Germany," in Economic Consequences of Immigration to Germany, eds. Gunter Steinmann and Ralf Ulrich, Springer-Verlag.

Green, David A., 1999. "Immigrant Occupational Attainment: Assimilation and Mobility over Time," Journal of Labor Economics, 17(1): 49-79.

Green, David A., and Christopher Worswick. 2012. "Immigrant Earnings Profiles in the Presence of Human Capital Investment: Measuring Cohort and Macro Effects," Labour Economics, 19(2): 241-259.

Hansen, Jorgen and Magnus Lofstrom, 2009. "The Dynamics of Immigrant Welfare and Labor Market Behavior." Journal of Population Economics. 22 (4): 941-970.

Heston, Alan and Robert Summers, 1991. "The Penn World Table (Mark 5): An Expanded Set of International Comparisons, 1950-1988." Quarterly Journal of Economics, 156(2): 327-368.

Jaeger, David, 1997. "Reconciling the Old and New Census Bureau Education Questions: Recommendations for Researchers," Journal of Business \& Economic Statistics, 15(3): 300-309.

-, 2007. "Green Cards and the Location Choices of Immigrants in the United States, 1971-2000," Research in Labor Economics, 27:131-183.

Jaeger, David, Thomas Dohmen, Armin Falk, David Huffman, Uwe Sunde and Holger Bonin, 2010. "Direct Evidence on Risk Attitudes and Migration" Review of Economics and Statistics 92(3):684-689.

Jaeger, David A. and Marianne E. Page, 1996. "Degrees Matter: New Evidence on Sheepskin Effects in the Returns to Education," Review of Economics and Statistics, 78(4):733-740

Jasso G. and Rosenzweig, M. R., 1986. "What's in a Name? Country-of-Origin Influences on the Earnings of Immigrants in the United States." Research in Human Capital and Development 2(4):75-106.

-, 1990a. The New Chosen People: Immigrants in the United States. New York: Russell Sage Foundation.

-, 1990b. "Self-Selection and the Earnings of Immigrants: Comment," American Economic Review, 80(1):298-304.

—, 1995. "Do Immigrants Screened for Skills Do Better than Family-Reunification Immigrants?" International Migration Review 29: 85-111.

Kakwani, Nanak, "Large Sample Distribution of Several Inequality Measures," Living Standards Measurement Study Working Paper \#61, World Bank, 1990.

Kossoudji, Sherrie A. 1988. "English Language Ability and the Labor Market Opportunities of Hispanic and East Asian Immigrant Men," Journal of Labor Economics, 6 (2): 205-28.

—, 1989. "Immigrant Worker Assimilation: Is It a Labor Market Phenomenon?" Journal of Human Resources, 24(3) pp. 494-527.

Lalonde, Robert J. and Robert H. Topel (1991) "Immigrants in the American Labor Market: Quality, Assimilation, and Distributional Effects," The American Economic Review, 
81(2):297-302..

—, 1997. "Economic Impact of International Migration and the Economic Performance of Migrants," in Handbook of Population and Family Economics, eds. Mark R. Rosenzweig and Oded Stark, Amsterdam: Elsevier, 800-850.

Lofstrom, Magnus, 2002. "Labor Market Assimilation and the Self-Employment Decision of Immigrant Entrepreneurs. Journal of Population Economics, 15(1):83-114.

Lin, Carl. 2013. "Earnings Gap, Cohort Effect and Economic Assimilation of Immigrants from Mainland China, Hong Kong, and Taiwan in the United States," Review of International Economics, 21(2):249-265.

Pischke, Jörn-Steffen and Johannes Velling, 1997. "Employment Effects of Immigration to Germany: An Analysis Based on Local Labor Markets," The Review of Economics and Statistics, 79(4):594-604.

Portes, Alejandro, and Robert Bach, 1985. Latin Journey: Cuban and Mexican Immigrants in the United States. University of California Press, Berkeley, CA.

Reimers, Cordelia, 1985. "Cultural Differences in Labor Force Participation among Married Women," American Economic Review, 75(2): 251-255.

Reimers, David, 1996. "Third World Immigration to the United States." in Duleep, H., Wunnava, P.V. (Eds.), Immigrants and Immigration Policy: Individual Skills, Family Ties, and Group Identities. JAI Press, Greenwich, CT.

Rivera-Batiz, Francisco, 1992. "English Language Proficiency and the Earnings of Young Immigrants in U.S. Labor Markets," Policy Studies Review, 11(2):165-75.

Rivera-Batiz, Francisco and Sechzer, Selig, 1991. "Substitution and Complementarity between Immigrant and Native Labor in the United States," in U.S. Immigration Policy Reform in the 1980s, eds. F. L. Rivera-Batiz, S.L. Sechzer, and Ira N. Gang, New York: Praeger, 89-116.

Schoeni, Robert F. 1997. "New Evidence on the Economic Progress of Foreign-Born Men in the 1970s and 1980s," Journal of Human Resources, 32(4):683-740.

Vanderkamp, John, 1972. "Return Migration: Its Significance and Behavior, Western Economic Journal, 10(4):460-65.

Van Tubergen, Frank and Herman van de Werfhorst, 2007. "Post-Immigration Investments in Education: A Study of Immigrants in the Netherlands," Demography, 44(4):883-898.

Waldinger, R., 1989. "Structural Opportunity or Ethnic Advantage? Immigrant Business Development in New York," International Migration Review, 23(1):48-72.

Warren, Robert and Ellen Percy Kraly. 1985. The Elusive Exodus: Emigration from the United States. Washington, DC: Population Reference Bureau.

Yezer, Anthony M.J. and Lawrence Thurston, 1976. "Migration Patterns and Income Change," Southern Economic Journal, 42(4):693-702.

Zorlu, Aslan. 2013. "Occupational Adjustment of Immigrants in the Netherlands," Journal of International Migration and Integration November, 14(4): 711-731. 


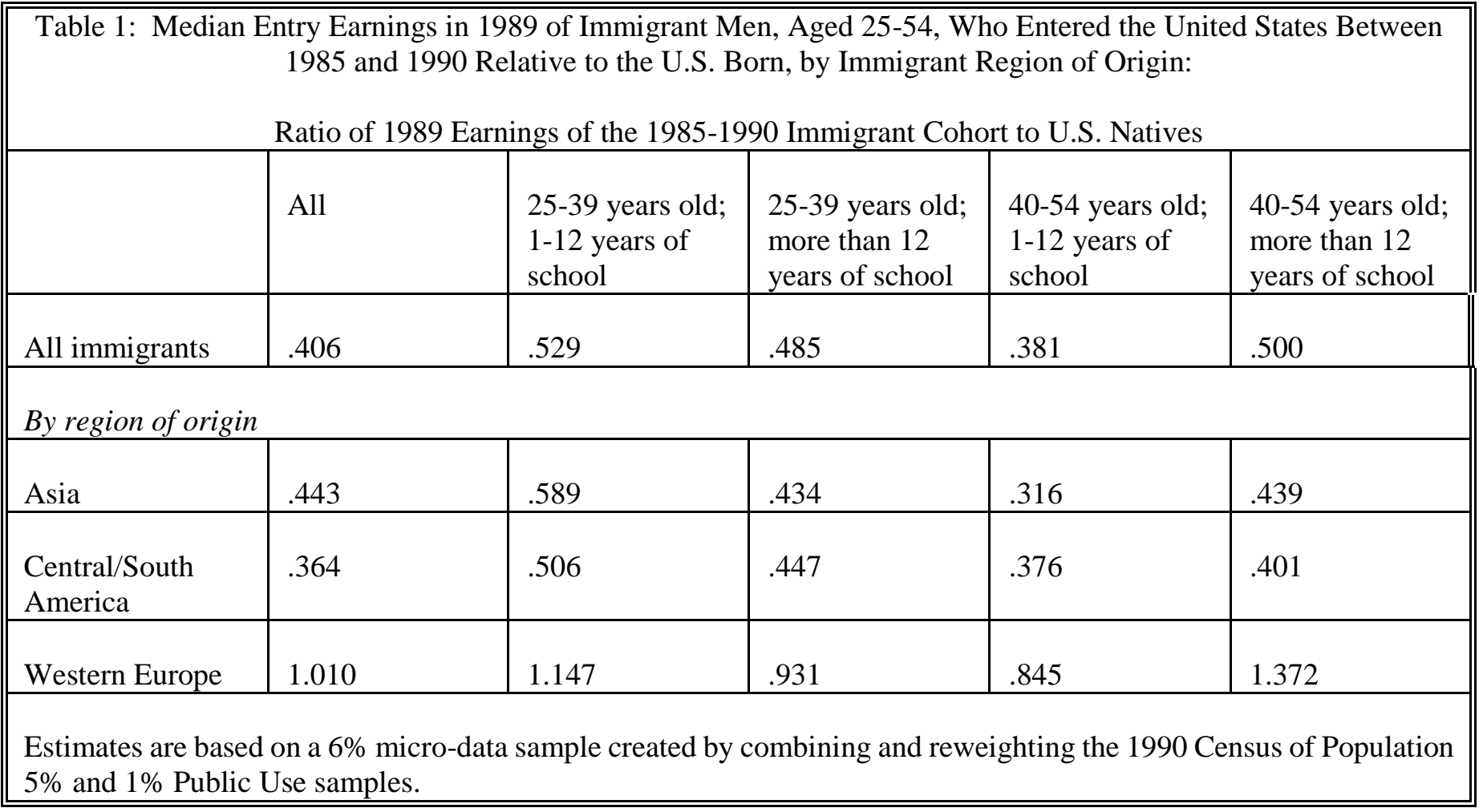


Table 2: Changes in the Explanatory Power of Country of Origin as Time in U.S. Increases 1960-1980 Decennial Census Data

(Bootstrap standard errors for $\mathrm{R}^{2}$ in parentheses)

\begin{tabular}{|c|c|c|c|c|}
\hline Entry Cohort, Census year & $\begin{array}{l}\mathrm{R}^{2} \text { for human } \\
\text { capital model }\end{array}$ & $\begin{array}{c}\mathrm{R}^{2} \text { for human } \\
\text { capital model with } \\
\text { country-of-origin } \\
\text { variables }\end{array}$ & $\begin{array}{l}\text { Change in } \mathrm{R}^{2} \\
\text { from adding } \\
\text { country-of- } \\
\text { origin variables }\end{array}$ & $\begin{array}{c}\text { Percentage } \\
\text { change in } \mathrm{R}^{2} \\
\text { from adding } \\
\text { country-of-origin } \\
\text { variables }\end{array}$ \\
\hline \multicolumn{5}{|l|}{$1955-59$ cohort } \\
\hline At entry: 1960 & $.1154(.0131)$ & $.2758(.0188)$ & .1604 & 139.0 \\
\hline Ten years later: 1970 & $.1606(.0095)$ & $.2493(.0099)$ & .0887 & 55.2 \\
\hline \multicolumn{5}{|l|}{$1965-69$ cohort } \\
\hline At entry: 1970 & $.0812(.0086)$ & $.1731(.0123)$ & .0919 & 113.2 \\
\hline Ten years later: 1980 & $.1663(.0055)$ & $.2065(.0058)$ & .0402 & 24.2 \\
\hline \multicolumn{5}{|c|}{$\begin{array}{l}\text { The base model is the regression of individual log(earnings) on experience, experience squared, and education. In the } \\
\text { second model, region/country dummies and region/country interactions with education and experience are included for } \\
\text { Africa, Britain, Canada, China/Taiwan, Cuba, Czechoslovakia, Germany, Greece, Hungary, India, Ireland, Islamic } \\
\text { Southwest Asia, Italy, Jamaica, Japan, Korea, Mexico, Other Asia, Oceania, Other Communist Europe, Other } \\
\text { Non-Communist Europe, Other Central America, Philippines, Poland, Portugal, South America, and Yugoslavia. } \\
\text { Estimates are based on the } 19805 \% \text { "A" PUMS, the } 19701 \% \text { State PUMS based on the } 5 \% \text { questionnaire, and the } \\
19601 \% \text { PUMS. Sample size information for all entry cohorts, at entry and } 10 \text { years later, including the more recent } \\
\text { cohorts analyzed in Tables } 7 \text { and 8, is given in note } 21 \text {. }\end{array}$} \\
\hline
\end{tabular}




\begin{tabular}{|c|c|}
\hline \multicolumn{2}{|c|}{$\begin{array}{c}\text { Table 2a: Changes in the Explanatory Power of the Base Model for } \\
\text { U.S.-Born Men } \\
\text { 1960-1980 Decennial Census Data }\end{array}$} \\
\hline Age, Census year & $\mathrm{R}^{2}$ for Base Model \\
\hline $25-54,1960$ & .1317 \\
\hline $35-64,1970$ & .1475 \\
\hline Change in $R^{2}$ & .0158 \\
\hline $25-54,1970$ & .1312 \\
\hline $35-64,1980$ & .1143 \\
\hline Change in $R^{2}$ & -.0169 \\
\hline $\begin{array}{l}\text { The base model is } \\
\text { experience square }\end{array}$ & ndividual $\log$ (earnings) on experience \\
\hline
\end{tabular}




\begin{tabular}{|c|c|c|c|c|}
\hline \multicolumn{5}{|c|}{$\begin{array}{l}\text { (Coefficients of Variation in Percentages) } \\
\text { (Weighted by Initial Cohort Size) } \\
\text { (Standard Errors of CV in Parentheses) }\end{array}$} \\
\hline Entry Cohort, Census year & $\begin{array}{l}\text { Young } \\
\text { Low Education }\end{array}$ & $\begin{array}{l}\text { Young } \\
\text { High Education }\end{array}$ & $\begin{array}{l}\text { Old } \\
\text { Low Education }\end{array}$ & $\begin{array}{l}\text { Old } \\
\text { High Education }\end{array}$ \\
\hline 1955-59 cohort & & & & \\
\hline At entry: 1960 & $46.6(2.641)$ & $37.2(2.590)$ & $39.0(3.130)$ & $39.3(3.210)$ \\
\hline Ten years later: 1970 & $21.1(0.894)$ & $17.5(2.047)$ & $24.9(1.778)$ & $18.3(2.731)$ \\
\hline Change in $\mathrm{CV}$ & -25.5 & -19.7 & -14.1 & -21.0 \\
\hline Percentage Change in CV & -54.7 & -52.9 & -36.1 & -53.4 \\
\hline 1965-69 cohort & & & & \\
\hline At entry: 1970 & $28.9(1.459)$ & $34.7(1.993)$ & $30.6(2.233)$ & $39.6(1.695)$ \\
\hline Ten years later: 1980 & $25.3(1.280)$ & $18.4(1.128)$ & $24.3(2.018)$ & $29.5(1.258)$ \\
\hline Change in $\mathrm{CV}$ & -3.6 & -16.3 & -6.3 & -10.1 \\
\hline Percentage Change in CV & -12.5 & -47.0 & -20.6 & -25.5 \\
\hline
\end{tabular}




\begin{tabular}{|c|c|c|c|c|}
\hline \multicolumn{5}{|c|}{$\begin{array}{c}\text { Table 3a: Changes in the Dispersion of Individual Earnings } \\
\text { U.S. -Born Men } \\
\text { 1960-1980 Decennial Census Data } \\
\text { (Coefficients of Variation in Percentages) } \\
\end{array}$} \\
\hline Age, Census year & $\begin{array}{l}\text { Young } \\
\text { Low Education }\end{array}$ & $\begin{array}{l}\text { Young } \\
\text { High Education }\end{array}$ & $\begin{array}{l}\text { Old } \\
\text { Low Education }\end{array}$ & $\begin{array}{l}\text { Old } \\
\text { High Education }\end{array}$ \\
\hline $25-54,1960$ & 63.5 & 81.5 & 73.6 & 71.7 \\
\hline $35-64,1970$ & 68.7 & 64.9 & 83.9 & 71.3 \\
\hline Change in $C V$ & 5.2 & -16.6 & 10.3 & -0.4 \\
\hline Percentage Change in $\mathrm{CV}$ & 8.2 & -20.4 & 14.0 & -.6 \\
\hline $25-54,1970$ & 60.7 & 72.3 & 72.2 & 66.2 \\
\hline $35-64,1980$ & 73.2 & 63.7 & 96.5 & 73.8 \\
\hline Change in $\mathrm{CV}$ & 12.5 & -8.6 & 24.3 & 7.6 \\
\hline Percentage Change in $C V$ & 20.6 & -11.9 & 33.7 & 11.5 \\
\hline $\begin{array}{l}\text { Young: aged 25-39 in the y } \\
\text { Old: aged 40-54 in the year } \\
\text { Low Education: } 1-12 \text { years }\end{array}$ & irst Census used & $\begin{array}{l}\text { e comparison. } \\
\text { omparison. } \\
\text { greater than } 12 \\
\end{array}$ & & \\
\hline
\end{tabular}




\begin{tabular}{|c|c|c|}
\hline \multirow[b]{2}{*}{ Pattern of Emigration } & \multicolumn{2}{|c|}{ Type of Analysis } \\
\hline & $\begin{array}{l}\text { Addition to } \mathrm{R}^{2} \text { Adding } \\
\text { Country-of-Origin } \\
\text { Variables }\end{array}$ & $\begin{array}{l}\text { Dispersion of Median } \\
\text { Earnings }\end{array}$ \\
\hline $\begin{array}{l}\text { Left or right tail of each country-of-origin earnings distribution. } \\
\text { (The unsuccessful, or the successful, of each country-of-origin } \\
\text { group emigrate.) }\end{array}$ & - & NO BIAS \\
\hline Center of each country-of-origin earnings distribution. & + & NO BIAS \\
\hline $\begin{array}{l}\text { Right tail of the earnings distribution for low-earning } \\
\text { country-of-origin groups and left tail of the earnings distribution } \\
\text { for high-earning country-of-origin groups. }\end{array}$ & - & - \\
\hline $\begin{array}{l}\text { Right tail of the earnings distribution for high-earning } \\
\text { country-of-origin groups and left tail of the earnings distribution } \\
\text { for low-earning country-of-origin groups. }\end{array}$ & - & + \\
\hline $\begin{array}{l}\text { + indicates that emigration bias works to overstate country-of-ori } \\
\text { - indicates that emigration bias works to understate country-of-or }\end{array}$ & $\begin{array}{l}\text { convergence. } \\
\text { convergence. }\end{array}$ & \\
\hline
\end{tabular}




\begin{tabular}{|c|c|c|c|c|c|c|c|c|}
\hline \multirow[b]{2}{*}{$\begin{array}{l}\text { Entry Cohort, } \\
\text { Census Year }\end{array}$} & \multicolumn{4}{|c|}{ LOW EMIGRATION } & \multicolumn{4}{|c|}{ HIGH EMIGRATION } \\
\hline & $\begin{array}{l}\mathrm{R}^{2} \text { for } \\
\text { human } \\
\text { capital } \\
\text { model }\end{array}$ & $\begin{array}{l}\mathrm{R}^{2} \text { for human } \\
\text { capital model } \\
\text { with } \\
\text { country-of- } \\
\text { origin } \\
\text { variables } \\
\end{array}$ & $\begin{array}{l}\text { Change in } \\
\mathrm{R}^{2} \text { from } \\
\text { adding } \\
\text { country-of- } \\
\text { origin } \\
\text { variables } \\
\end{array}$ & $\begin{array}{l}\text { Percentage } \\
\text { change in } \mathrm{R}^{2} \\
\text { from adding } \\
\text { country-of- } \\
\text { origin } \\
\text { variables } \\
\end{array}$ & $\begin{array}{l}\mathrm{R}^{2} \text { for human } \\
\text { capital } \\
\text { model }\end{array}$ & $\begin{array}{l}\mathrm{R}^{2} \text { for human } \\
\text { capital model } \\
\text { with } \\
\text { country-of- } \\
\text { origin variables }\end{array}$ & $\begin{array}{l}\text { Change in } \mathrm{R}^{2} \\
\text { from adding } \\
\text { country-of- } \\
\text { origin } \\
\text { variables }\end{array}$ & $\begin{array}{l}\text { Percentage } \\
\text { change in } R^{2} \\
\text { from adding } \\
\text { country-of- } \\
\text { origin } \\
\text { variables } \\
\end{array}$ \\
\hline \multicolumn{9}{|l|}{ 1955-59 cohort } \\
\hline At entry: 1960 & $\begin{array}{l}.1108 \\
(.0176) \\
\end{array}$ & $\begin{array}{c}.2458 \\
(.0231) \\
\end{array}$ & .1283 & 109.2 & $\begin{array}{l}.0620 \\
(.0141) \\
\end{array}$ & $\begin{array}{c}.2460 \\
(.0351) \\
\end{array}$ & .1840 & 296.7 \\
\hline $\begin{array}{l}\text { Ten years later: } \\
1970\end{array}$ & $\begin{array}{l}.1109 \\
(.0184) \\
\end{array}$ & $\begin{array}{l}.2061 \\
(.0261) \\
\end{array}$ & .0952 & 85.8 & $\begin{array}{l}.1449 \\
(.0247) \\
\end{array}$ & $\begin{array}{l}.2111 \\
(.0270) \\
\end{array}$ & .0662 & 45.7 \\
\hline \multicolumn{9}{|l|}{ 1965-69 cohort } \\
\hline At entry: 1970 & $\begin{array}{l}.0265 \\
(.0078) \\
\end{array}$ & $\begin{array}{c}.0912 \\
(.0126) \\
\end{array}$ & .0647 & 244.1 & $\begin{array}{l}.1151 \\
(.0149) \\
\end{array}$ & $\begin{array}{c}.1943 \\
(.0195) \\
\end{array}$ & .0792 & 68.8 \\
\hline $\begin{array}{l}\text { Ten years later: } \\
1980\end{array}$ & $\begin{array}{l}.0992 \\
(.0064)\end{array}$ & $\begin{array}{l}.1250 \\
(.0070)\end{array}$ & .0258 & 26.0 & $\begin{array}{l}.1546 \\
(.0107)\end{array}$ & $\begin{array}{l}.1914 \\
(.0121)\end{array}$ & .0368 & 23.8 \\
\hline
\end{tabular}




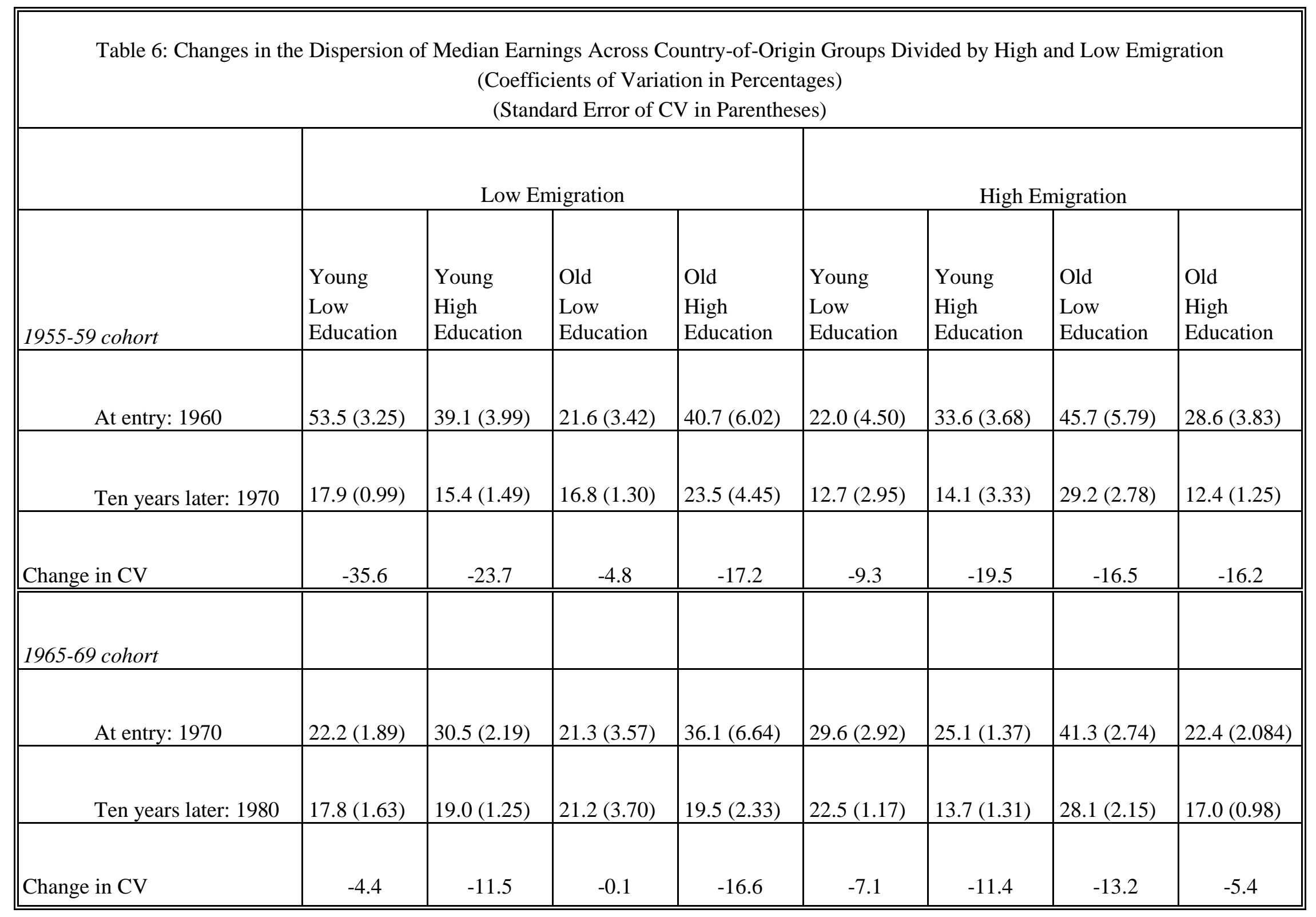




\begin{tabular}{|c|c|c|c|c|}
\hline \multicolumn{5}{|c|}{$\begin{array}{c}\text { Table 7: Changes in the Explanatory Power of Country of Origin as Time in U.S. Increases } \\
\text { 1980-2000 Decennial Census Data } \\
\text { (Bootstrap standard errors for } \mathrm{R}^{2} \text { in parentheses) }\end{array}$} \\
\hline Entry Cohort, Census year & $\begin{array}{l}\mathrm{R}^{2} \text { for human } \\
\text { capital model }\end{array}$ & $\begin{array}{l}\mathrm{R}^{2} \text { for human } \\
\text { capital model with } \\
\text { country-of-origin } \\
\text { variables }\end{array}$ & $\begin{array}{l}\text { Change in } \mathrm{R}^{2} \\
\text { from adding } \\
\text { country-of-orig } \\
\text { in variables }\end{array}$ & $\begin{array}{c}\text { Percentage } \\
\text { change in } \mathrm{R}^{2} \\
\text { from adding } \\
\text { country-of-origin } \\
\text { variables }\end{array}$ \\
\hline \multicolumn{5}{|l|}{ 1975-80 cohort } \\
\hline At entry: 1980 & $0.085(0.003)$ & $0.165(0.004)$ & 0.080 & 94.80 \\
\hline Ten years later: 1990 & $0.192(0.005)$ & $0.256(0.005)$ & 0.065 & 33.68 \\
\hline \multicolumn{5}{|l|}{ 1985-90 cohort } \\
\hline At entry: 1990 & $0.112(0.003)$ & $0.213(0.004)$ & 0.101 & 90.85 \\
\hline Ten years later: 2000 & $0.161(0.004)$ & $0.233(0.004)$ & 0.072 & 44.93 \\
\hline \multicolumn{5}{|c|}{$\begin{array}{l}\text { The base model is the regression of individual log(earnings) on experience, experience squared, and education. In the } \\
\text { second model, region/country dummies and region/country interactions with education and experience are included for } \\
\text { Africa, Britain, Canada, China/Taiwan, Cuba, Czechoslovakia, Germany, Greece, Hungary, India, Ireland, Islamic } \\
\text { Southwest Asia, Italy, Jamaica, Japan, Korea, Mexico, Other Asia, Oceania, Other Communist Europe, Other } \\
\text { Non-Communist Europe, Other Central America, Philippines, Poland, Portugal, South America, and Yugoslavia. } \\
\text { Estimates are based on the 1980, 1990, and } 2000 \text { Census of Population Public Use Samples. A } 6 \text { percent micro-data } \\
\text { sample is created by combining and reweighting the } 5 \% \text { and } 1 \% \text { Public Use files for each decennial census. }\end{array}$} \\
\hline
\end{tabular}




\begin{tabular}{|c|c|c|c|c|}
\hline \multicolumn{5}{|c|}{$\begin{array}{l}\text { Table 8: Changes in the Dispersion of Median Earnings Across Country of Origin } \\
\text { for the 1975-80 Cohort of Immigrant Men as Time in U.S. Increases } \\
\text { 1980-2000 Decennial Census Data } \\
\text { (Coefficients of Variation in Percentages) } \\
\text { (Weighted by Initial Cohort Size) } \\
\text { (Standard Errors of CV in Parentheses) } \\
\end{array}$} \\
\hline Entry Cohort, Census year & $\begin{array}{l}\text { Young } \\
\text { Low Education }\end{array}$ & $\begin{array}{l}\text { Young } \\
\text { High Education }\end{array}$ & $\begin{array}{l}\text { Old } \\
\text { Low Education }\end{array}$ & $\begin{array}{l}\text { Old } \\
\text { High Education }\end{array}$ \\
\hline \multicolumn{5}{|l|}{ 1975-79 cohort } \\
\hline At entry: 1980 & $34.6(.035)$ & $55.1(.0343)$ & $52.1(.0500)$ & $57.6(.0182)$ \\
\hline Ten years later: 1990 & $26.4(.019)$ & $23.1(.0127)$ & $28.6(.0190)$ & $32.5(.0300)$ \\
\hline Change in CV & -8.2 & -32.0 & -23.5 & -25.1 \\
\hline Percentage Change in CV & -23.7 & -58.1 & -45.1 & -43.6 \\
\hline \multicolumn{5}{|l|}{$1985-89$ cohort } \\
\hline At entry: 1990 & $5.9(0.152)$ & $8.4(0.128)$ & $9.2(0.392)$ & $12(0.130)$ \\
\hline Ten years later: 2000 & $4.6(0.105)$ & $5.6(0.07)$ & $5.5(0.118)$ & $6.9(0.141)$ \\
\hline Change in $C V$ & -1.3 & -2.8 & -3.7 & -5.1 \\
\hline Percentage Change in $C V$ & -21.9 & -33 & -40.6 & -42.4 \\
\hline
\end{tabular}


Figure 1: The Earnings Trajectories of Immigrants

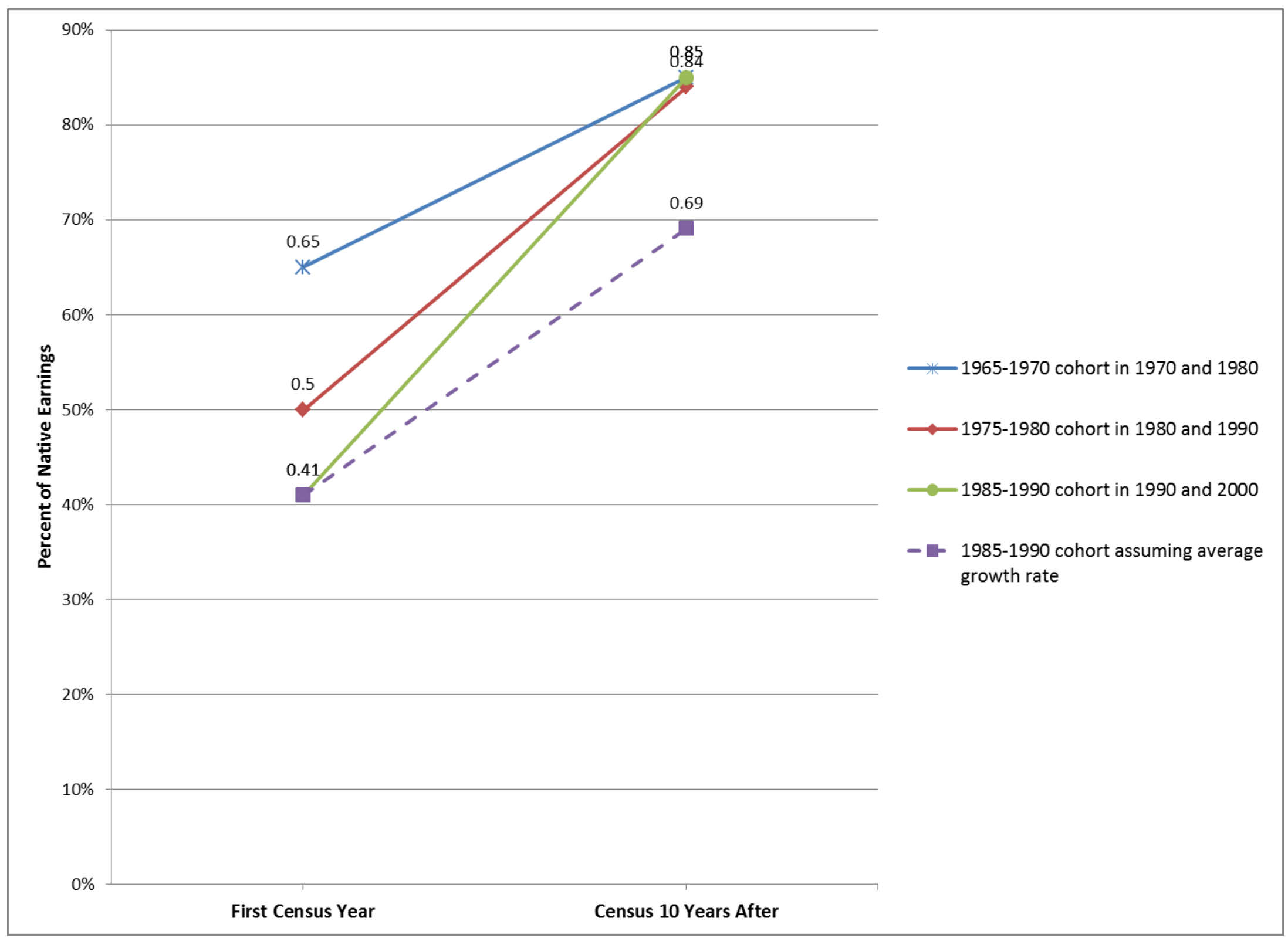


Figure 2: Hypothetical Emigration Patterns as a Function of the U.S. Earnings of Immigrants

Panel A

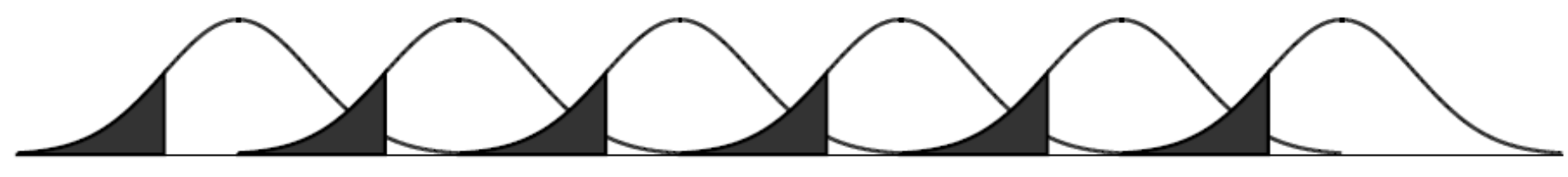

Panel B

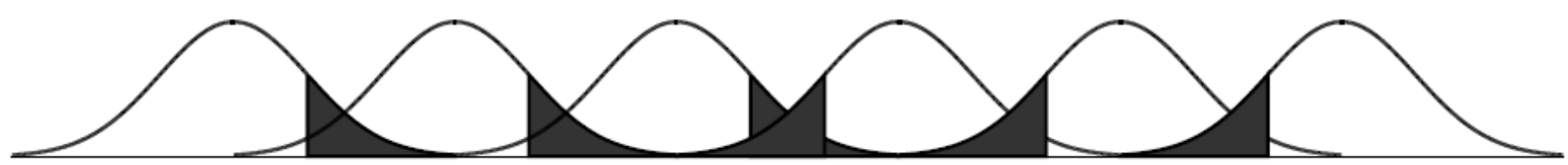

